\title{
A Review of Physical and Numerical Approaches for the Study of Gas Stirring in Ladle Metallurgy
}

\author{
YU LIU, MIKAEL ERSSON, HEPING LIU, PÄR GÖRAN JÖNSSON, and YONG GAN
}

This article presents a review of the research into gas stirring in ladle metallurgy carried out over the past few decades. Herein, the physical modeling experiments are divided into four major areas: (1) mixing and homogenization in the ladle; (2) gas bubble formation, transformation, and interactions in the plume zone; (3) inclusion behavior at the steel-slag interface and in the molten steel; and (4) open eye formation. Several industrial trials have also been carried out to optimize gas stirring and open eye formation. Approaches for selecting criteria for scaling to guarantee flow similarity between industrial trials and physical modeling experiments are discussed. To describe the bubble behavior and two-phase plume structure, four main mathematical models have been used in different research fields: (1) the quasi-single-phase model, (2) the volume of fluid (VOF) model, (3) the Eulerian multiphase (E-E) model, and (4) the Eulerian-Lagrangian (E-L) model. In recent years, the E-E model has been used to predict gas stirring conditions in the ladle, and specific models in commercial packages, as well as research codes, have been developed gradually to describe the complex physical and chemical phenomena. Furthermore, the coupling of turbulence models with multiphase models is also discussed. For physical modeling, some general empirical rules have not been analyzed sufficiently. Based on a comparison with the available experimental results, it is found that the mathematical models focusing on the mass transfer phenomenon and inclusion behaviors at the steel-slag interface, vacuum degassing at the gas-liquid interface, dissolution rate of the solid alloy at the liquid-solid interface, and the combination of fluid dynamics and thermodynamics need to be improved further. To describe industrial conditions using mathematical methods and improve numerical modeling, the results of physical modeling experiments and industrial trials must offer satisfactory validations for the improvement of numerical modeling.

https://doi.org/10.1007/s11663-018-1446-x

(C) The Author(s) 2018

\section{INTRODUCTION}

PRODUCTION of clean steel requires strict control of impurity elements, such as $\mathrm{O}, \mathrm{H}$, and $\mathrm{N}$, during ladle metallurgy. In addition, the content of nonmetallic inclusions in steel is an important factor affecting the quality of steel. To remove the inclusions, gas bubbling plays an important role in the steel metallurgy. This process is usually applied in the ladle, tundish, and continuous casting processes. Gas bubbling can increase

YU LIU is with Central Iron and Steel Research Institute, 100081 Beijing, P.R. China and also with the Unit of Processes, Department of Materials Science and Engineering, KTH-Royal Institute of Technology, 10044 Stockholm, Sweden. Contact. e-mail: yuliu2@kth.se MIKAEL ERSSON and PÄR GÖRAN JÖNSSON are with the Unit of Processes, Department of Materials Science and Engineering, KTH-Royal Institute of Technology. HEPING LIU and YONG GAN are with Central Iron and Steel Research Institute.

Manuscript submitted May 12, 2018.

Article published online November 20, 2018. the inclusion removal rate by adhesion or wake flow capture. Moreover, gas stirring is an important means to offer the fluid dynamics and homogenization of the molten steel with respect to alloy content and temperature and to promote reactions at the steel-slag interface. ${ }^{[1-7]}$ However, gas bubbling can also intensify the fluctuations of the steel-slag interface, and this may cause splashing and exposure of the steel to the atmosphere.

A large number of articles have been published on the study of gas stirring in ladles, and mathematical models and physical models have been used either separately or together according to the research focus. Several reviews have summarized previous studies ${ }^{[1,2,5-7]}$ involving cold experiments and mathematical modeling carried out several years ago. In Sichen's ${ }^{[5]}$ review, the understanding of mass transfer and inclusion behaviors, especially the interactions of different types of inclusions, was proposed as the area requiring further study. A good balance between modeling and experimental research was also proposed because experimental studies have become frequent in recent years. Iron et al. ${ }^{[6]}$ reported 
plume dynamics and Froude number similarity in detail. Moreover, the interfacial phenomenon and steel-slag reactions were also highlighted. Based on previous review works, the present article presents a review of the physical and numerical approaches used in the study of gas stirring in ladle metallurgy over the past 3 decades to give some options and find new and meaningful research directions, as well as desired experimental results for simulation validation. Previous contributions to the study of ladle metallurgy have been categorized into four major groups, as covered in the following sections. Section II: physical modeling experiments, Section III: industrial trials, Section IV: criteria for scaling between physical modeling experiments and industrial trials, and Section $\mathrm{V}$ : numerical models to study the gas-liquid zone in ladle refining.

\section{PHYSICAL MODELING EXPERIMENTS}

With the aim of improving clean steel's quality, many researchers $^{[8-11]}$ have paid attention to either one or several aspects of gas stirring in the ladle. Depending on the research goal, the previous physical modeling experiments in lab scale have been divided into four major groups: (1) mixing and homogenization in the ladle; (2) gas bubbling formation, transformation, and interaction in the plume zone; (3) inclusion behaviors at the steel-slag interface and in the molten steel; and (4) open eye formation.

\section{A. Mixing and Homogenization in the Ladle}

Mixing and homogenization in ladles are fundamentally important in metallurgical processes. Concerning this research, the following aspects have been studied: how the mixing time and flow pattern in the ladle are affected by the plug configuration with bottom blowing or top blowing ${ }^{8,12-20]}$ (that is, the plug number, plug location in the radial direction, and separation angle of dual plugs), the tracer injection point, ${ }^{[8,21]}$ and the sensor monitoring point. ${ }^{[8]}$ In addition, the mixing time defined by two degrees (95 and 99 pct) has been discussed in some works. ${ }^{[12,22]}$ The criteria for dynamic similarity ${ }^{[23,24]}$ in gas-stirred ladles have been investigated both theoretically and experimentally. In experiments, $\mathrm{KCl}, \mathrm{NaCl}$, or another conducting medium material is usually used as a tracer additive to enable the electrical conductivity to be determined by sensors. The mixing time is defined as the time at which the concentration of the tracer additive is continuously within \pm 5 pct of a well-mixed bulk value. Similarly, the time required to reach 95 pct tracer concentration is used to compare the homogenization conditions between various experimental configurations. In terms of the mixing condition, for single-plug injection, the optimal location of the plug is off-centered at 0.5 to $0.67 \mathrm{R}$ ( $\mathrm{R}$ is the ladle radius) ${ }^{[8,12,13,17,19]}$ and the optimal position for injection is on the tuyere-circle center plane opposing the center of the circle. ${ }^{[21]}$ In contrast, for dual plug, a separation angle (two groups of $45 \mathrm{deg}$ to $90 \mathrm{deg}$ to $135 \mathrm{deg}$ to $180 \mathrm{deg}$ and $60 \mathrm{deg}$ to $90 \mathrm{deg}$ to $120 \mathrm{deg}$ to $150 \mathrm{deg}$ to $180 \mathrm{deg}$ were analyzed) of $180 \mathrm{deg}$ is recommended, ${ }^{[8,14,19]}$ and the optimal location of the plugs is also at the midradius position. ${ }^{[8,14,17,19]}$ In addition, the optimal position for injection is at the center. ${ }^{[8]}$ An empirical expression for the 95 pct mixing time has been proposed as $\tau_{95 \mathrm{pct}}=$ $A * Q^{-x} * H^{-y} * R^{z}{ }^{[14,16]}$ Previous studies of the mixing and homogenization in ladle metallurgy are summarized in Table I.

\section{B. Gas Bubble Formation, Transformation, and Interactions in the Plume Zone}

After inert gas is injected into the liquid, bubbles generate, transform, collide, and break up during the rise in the bath because of the interactions between the liquid and the gas. Studies of the gas bubbling behavior in the plume zone of ladles are summarized in Table II. In this research field, many works ${ }^{[9,25-29]}$ have used water experiments to study the mean and fluctuating velocity distribution in the radial and axial directions, gas fraction profiles, bubble frequency, bubble penetration length, average bubble rising velocity, and the coalescence regime of discrete bubbles in the plume. The relative velocity between the gas and liquid, ${ }^{[30,31]}$ the agitation of the free surface, and the turbulence distribution $^{[32]}$ in the plume have also been discussed. It has been found that the velocity distribution is related to various flow rates and the aspect ratio of the liquid depth and the vessel diameter. In addition, the spatial distribution of the gas in the plume can be fully described by the correlation of the axial gas fraction and the modified Froude number: as the gas flow rate increases, the central axial velocity increases slightly and the radial velocity also increases, making the plume wider. Because of the different bubble characteristics along the central line of the vessel, the gas plume region is divided into the momentum, transition, bubble buoyancy, and surface regions from the nozzle exit toward the surface, ${ }^{[26,33]}$ as shown in Figure 1. In some works, systems of molten iron ${ }^{[34]}$ and Wood's metal ${ }^{[35,36]}$ using injected nitrogen, argon, or helium gas have been used to study the bubble behavior in the plume. Guo and Irons ${ }^{[37,38]}$ carried out water experiments using the $\mathrm{NaOH}-\mathrm{CO}_{2}$ system to simulate the diffusion-controlled decarburization process in liquid steel. More recently, a water-oil-air system was established by $\mathrm{Li}$ et al. ${ }^{[39]}$ to predict the bubble size distribution in the plume zone, as shown in Figure 2. Xu et al. ${ }^{[40]}$ studied the effect of the wettability on the formation of separated bubbles using a water model, and the phenomenon of how coaxial bubbles coalesce and how parallel bubbles bounce in one- and two-nozzle systems was shown by Wang et $a l^{[41]}$ in a series of water-based experiments. Ito and co-workers ${ }^{[42,43]}$ studied the behavior of a single rising bubble, and its volumetric mass transfer under vacuum degassing condition was reported. 


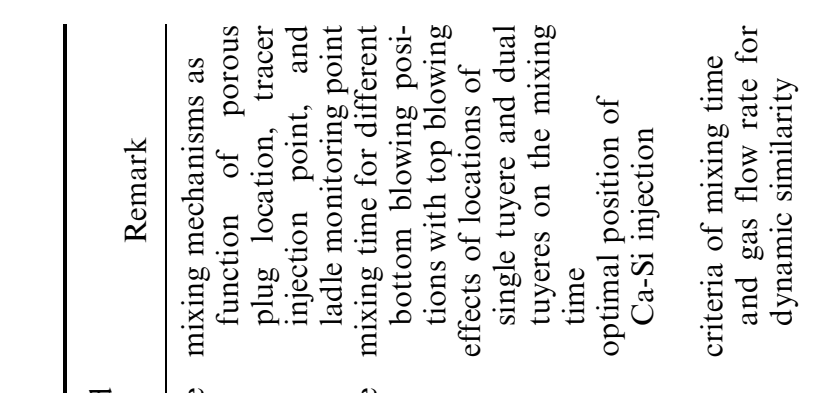

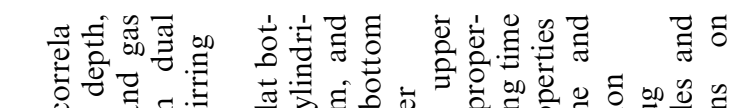

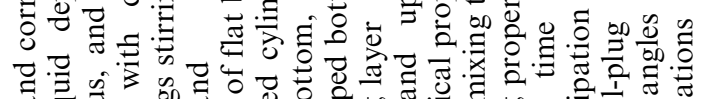

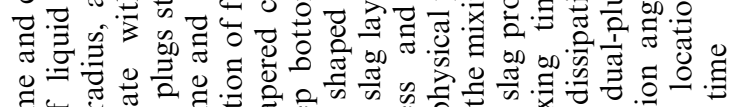

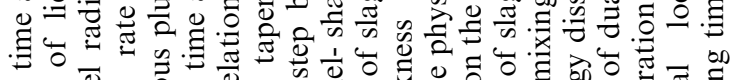

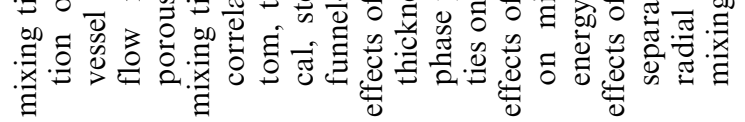

छ $\quad$ छ

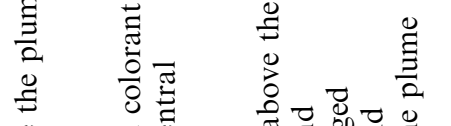

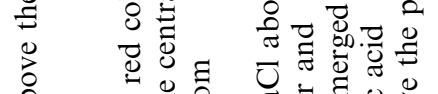

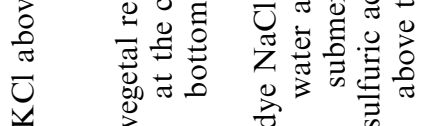

㲾

氙

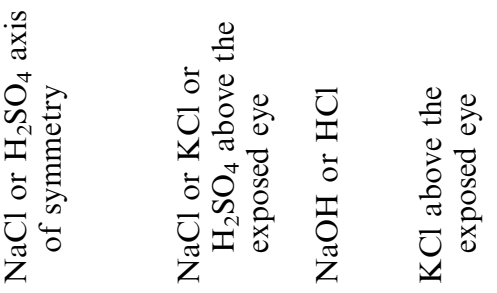

$\exists$

这

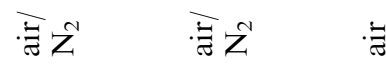

离

$\stackrel{\bar{\omega}}{\grave{\pi}}$

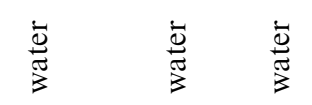

离

$\begin{array}{ll}\dot{\bar{\pi}} & \dot{\bar{m}} \\ \frac{\pi}{3} & 3\end{array}$

过

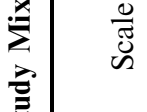

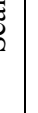

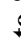

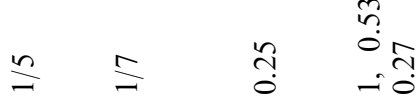

กับ

I

$\stackrel{m}{=}$

$\stackrel{\infty}{\leftrightarrows} 0$

我

$\overline{0}$

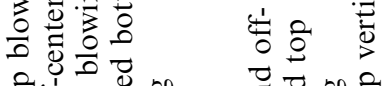

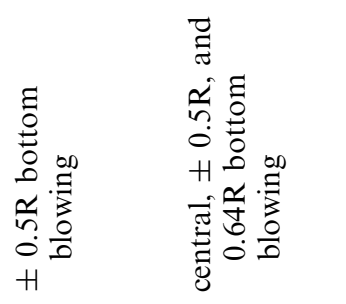

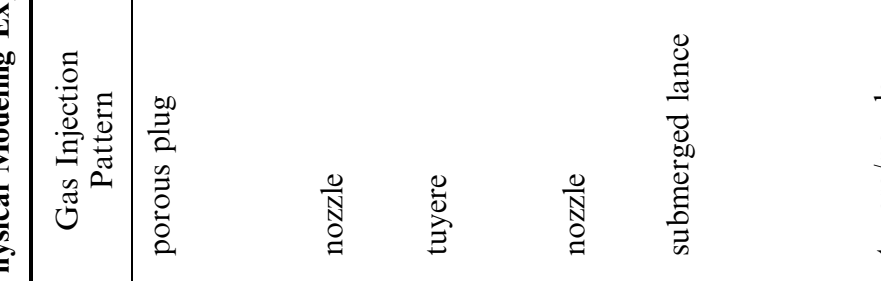

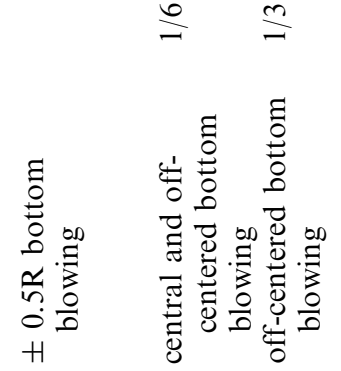

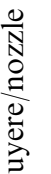<smiles>[13CH]</smiles>

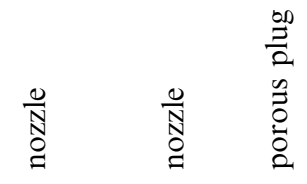

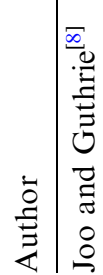
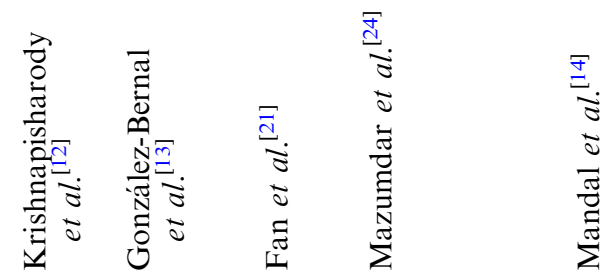

METALLURGICAL AND MATERIALS TRANSACTIONS B

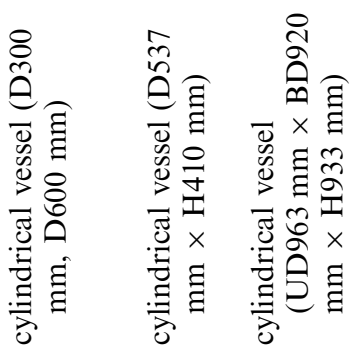

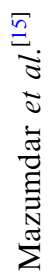

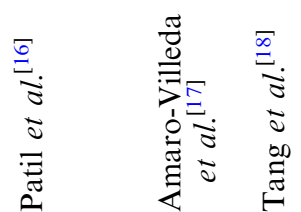




\section{Inclusion Behavior at the Steel-Slag Interface and in the Molten Steel}

Cold experiments of the inclusion behavior are summarized in Table III. Most of the particles are trapped by the slag layer and a small number of inclusion particles roll back into the molten steel. ${ }^{[4,45]}$ Gas bubbling can increase the inclusion removal rate because of the adhesion of inclusions to the bubbles or because the inclusions follow the wake flow of the bubbles. ${ }^{[46-48]}$ In some works, water modeling experiments ${ }^{[44,49]}$ have been used to compare the slag droplet entrainment and the removal contribution of the gas plume, as well as the buoyancy around the open eye. Thunman et al. ${ }^{[50]}$ used a Ga-In-Sn alloy with a melting temperature of $283 \mathrm{~K}$ to simulate the steel and $\mathrm{MgCl}_{2}$-glycerol (87 pct), as well as a hydrochloric acid solution to simulate the ladle slag. The Ga-In-Sn alloy-12 pet hydrochloric acid system showed better applicability for the prediction of slag particle entrainment around the open eye zone. In addition, Dayal et $a l^{[51]}$ studied the effect of the shear force on the particle droplet behavior at the steel-slag interface. Furthermore, an experimental approach was used by Yang et al.$^{[52]}$ to analyze the mechanism of nonmetallic inclusion removal by the wake flow. In their work, the effects of the bubble size, particle concentration, and inclusion particle size on the inclusion capture rate were studied in detail. Liu et al. ${ }^{[53]}$ studied and discussed the forces of nonmetallic inclusions at the steel-slag interface, and the inclusion separation from the molten steel to the slag was analyzed. Zhou et al. ${ }^{[54]}$ also studied the separation of nonmetallic inclusions at the steel-slag interface, and the effects of inclusion geometry and slag properties were investigated in detail.

\section{Open Eye Formation}

Last but not least, open eye formation is important in terms of the experimental analysis of gas bubbling in ladle metallurgy. The "open eye" is also known as the "spout eye" in ladle metallurgy. Its functions are to promote steel-slag reactions and to reduce the reoxidation reactions between clean steel and air. Moreover, under some conditions, the formation of the open eye is useful for promoting effective alloying. Because the open eye forms and the slag layer is pushed to the side, alloys can be added directly to the molten steel. The structure around the open eye zone is shown in Figure 3. ${ }^{[5]}$ Studies of the steel-slag interface and open eye formation are summarized in Table IV. Cold model experiments studying the formation of the open eye, spout height, and spout width during gas stirring have been carried out by many researchers. ${ }^{[10,17,19,50,51,55-61]}$ In this research area, water-silicon oil, water-bean oil, and water-heavy oil have been used to model the steel-slag interactions with the gas bubbling of air, nitrogen, or argon in physical modeling experiments. Mercury-oil, ${ }^{[10]}$ Ga-In-Sn alloy- $\mathrm{MgCl}_{2}$-glycerol (87 pct), and Ga-In-Sn alloy-hydrochloric acid solutions ${ }^{[59]}$ have also been used to model the molten steel. The obtained results show that the spout shape is well described by a Gaussian 


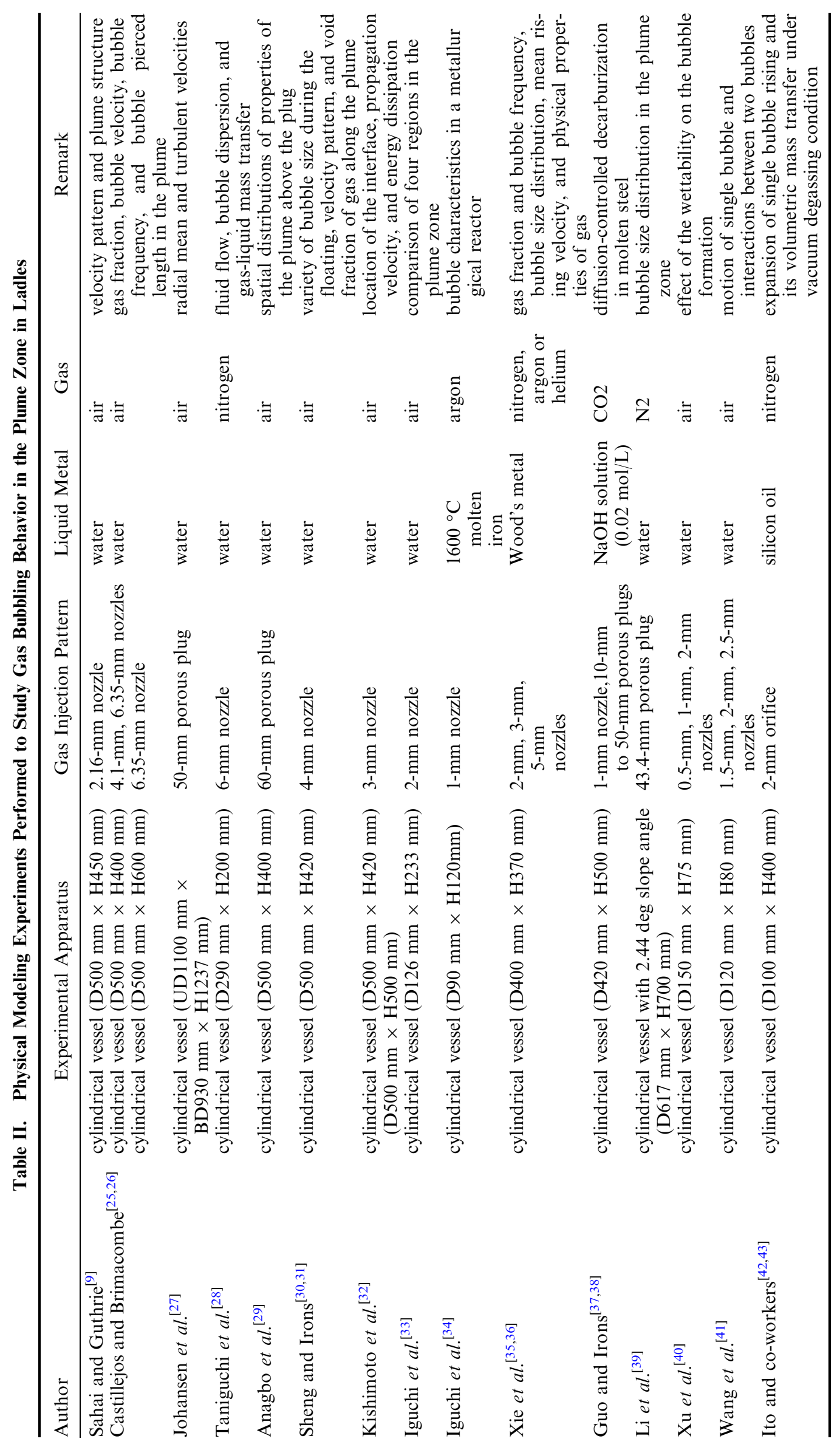


distribution. Furthermore, the empirical equation for open eye $\mathrm{e}^{[55,57,58,60,61]}$ has been modified based on parameters such as the density ratios of the bulk and slag phases, the Froude number, and the Reynolds

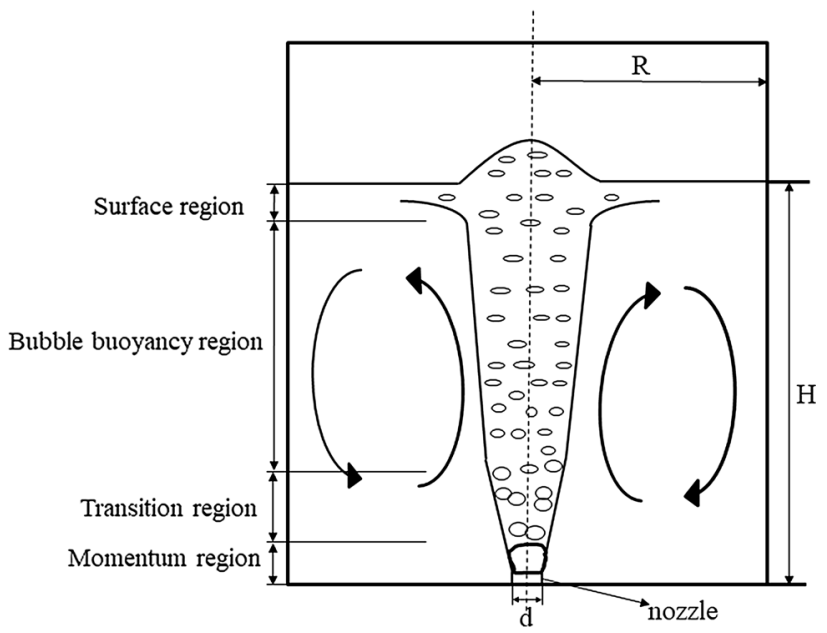

Fig. 1-Classification of the flow field in the plume. number. Recently, two up-to-date experimental works ${ }^{[19,62]}$ studying the effects of the slag layer thickness and the location and separation angle of dual plugs on the flow pattern and slag eye formation in the ladle have been reported.

In general, using physical modeling, it is possible to investigate the fluid dynamics phenomena, but it is difficult to study the phenomena related to the reaction kinetics in ladle metallurgy. For the physical modeling, required for the optimization of mixing and homogenization in ladles, the general empirical rules have not been analyzed sufficiently.

\section{INDUSTRIAL TRIALS}

Some industrial trials have also focused on studying the gas stirring in ladle metallurgy, and these are summarized in Table $\mathrm{V}$. The condition of molten slag and open eye formation in an industrial ladle is shown in Figure 4. Continuous temperature measurement has been achieved by means of thermocouples in a production ladle at SSAB AB, and this has been used to analyze the thermal stratification in molten steel during holding. A real plant experiment was performed at the

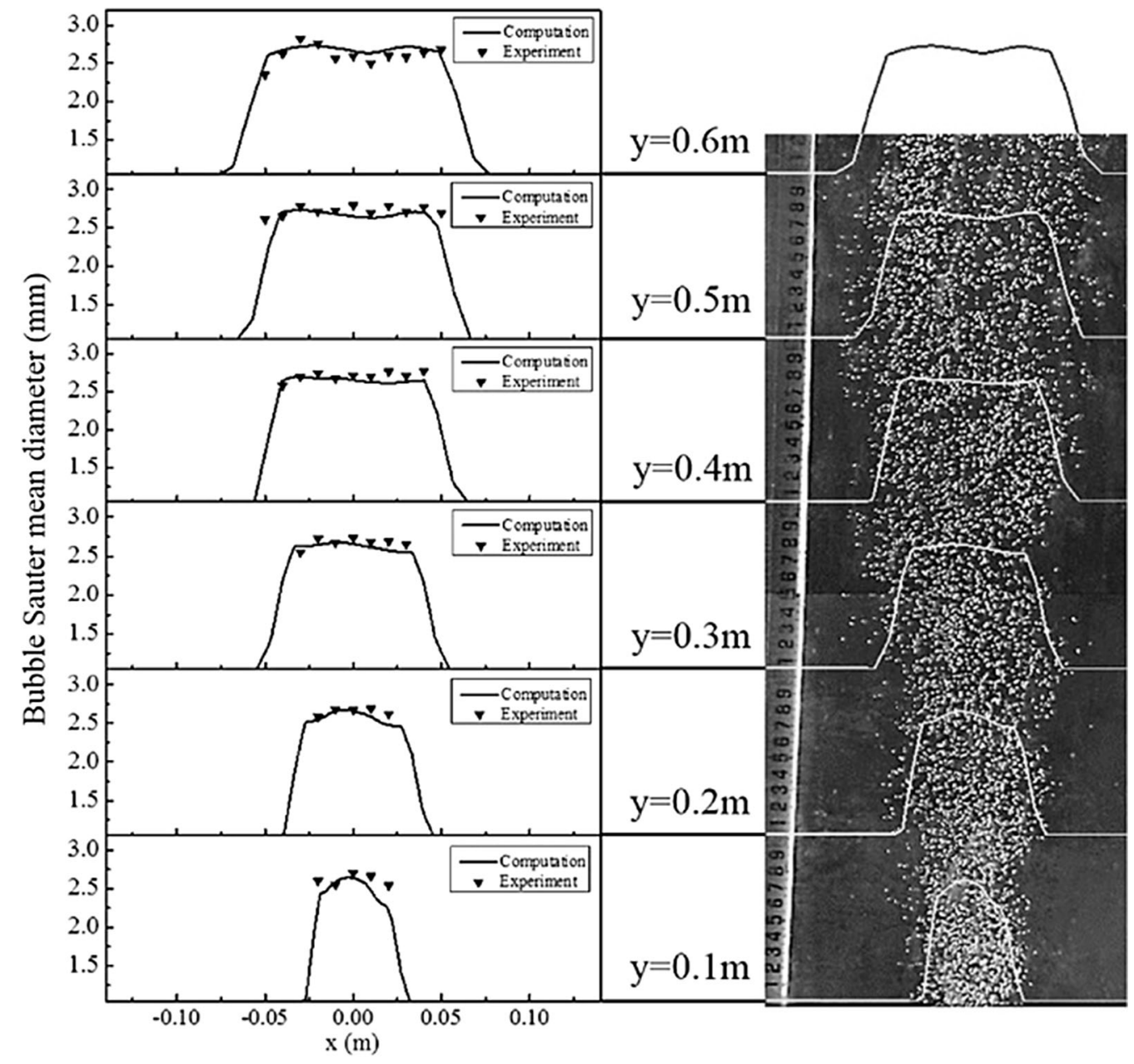

Fig. 2-Comparison of bubble diameter distribution from the modeling and experiments (reprinted from Ref. [39]). 


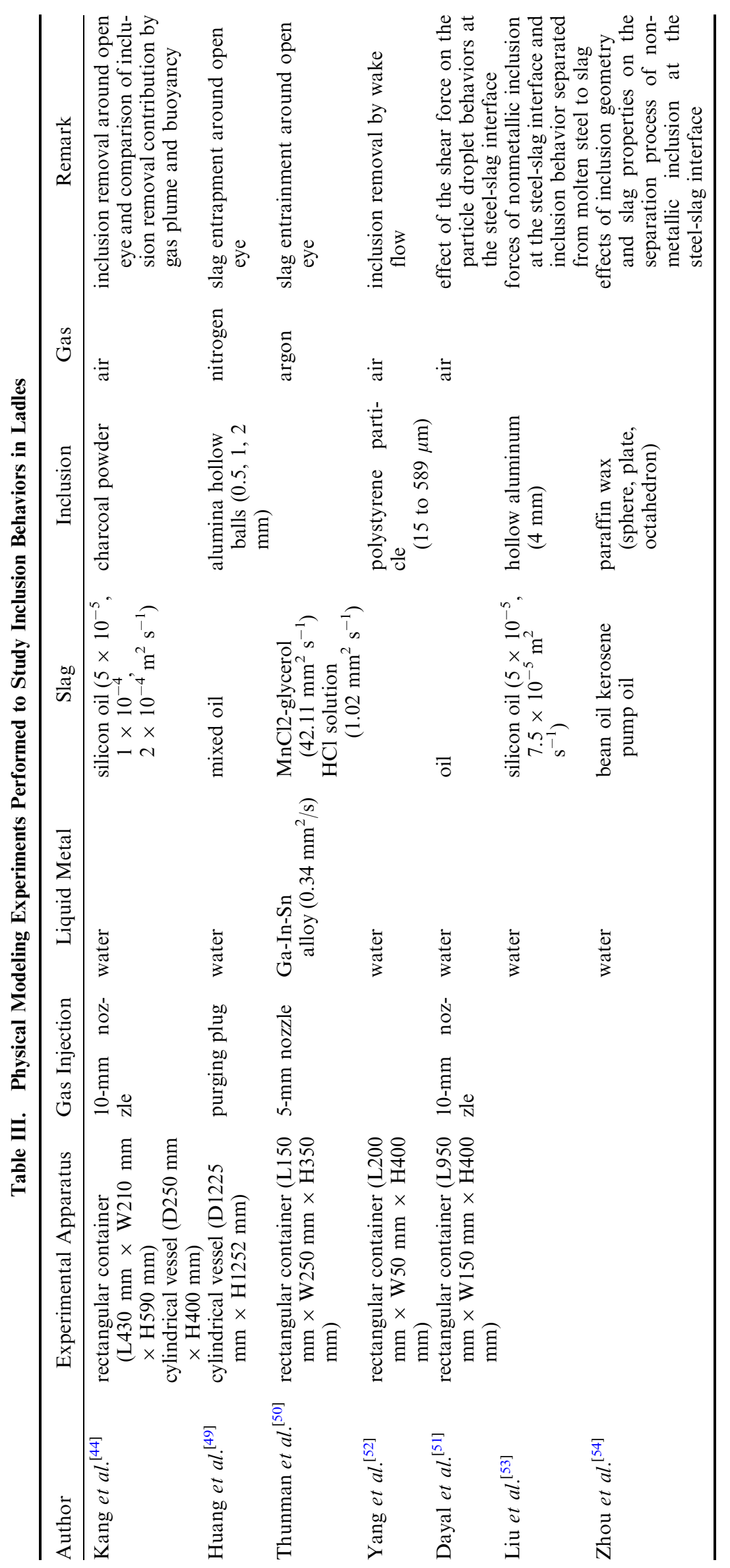




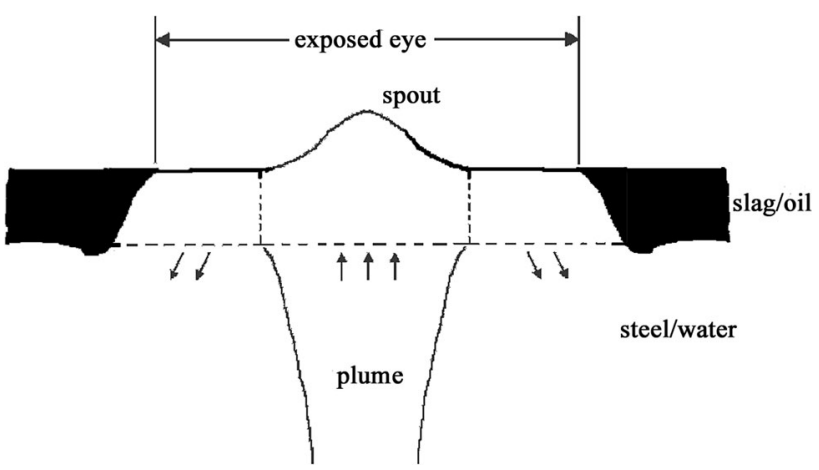

Fig. 3 - Schematic diagram of the open eye formation for a thin slag layer (reprinted from Ref. [55]).

Yawata Steel Works, Nippon Steel Corporation, to measure the open eye. The results were compared with the cold experimental data of Krishnapisharody and Schwerdtfeger. ${ }^{[10]}$ This plant experiment yielded dependable results for further open eye research. In addition, samples made by Uddeholm Tooling $\mathrm{AB}$ were used to study the slag droplets generated at the steel-slag interface by Thunman et al..$^{[50]}$ and Dayal et al. ${ }^{[5]}$ Moreover, in the work of Wu et al., ${ }^{[59,63,64]}$ the open eye area was measured in a ladle at Saarstahl AG. Specifically, the influence of the flow pattern on the mixing conditions and open eye formation in the industrial plant was evaluated. Furthermore, the analyses of the temperature distribution and heat transfer on the ladle lining during the preheating process ${ }^{[65]}$ and the teeming process ${ }^{[66]}$ were carried out based on a comparison of the industrial data and the data calculated by Glaser et al. A study of the influence of the stirring rate on the inclusion characteristics was carried out by Malmberg et $a l .{ }^{[45]}$ based on tool steel ladle data from Uddeholm AB. Recently, experiments were carried out at the SFIL Steelworks ${ }^{[67]}$ to study hydrogen degassing in the industrial process.

\section{CRITERIA FOR SCALING BETWEEN PHYS- ICAL MODELING EXPERIMENTS AND INDUS- TRIAL TRIALS}

The connection between physical modeling experiments and industrial trials is the scaling criteria. ${ }^{[3,68]}$ Using the geometric similarity $\left(\lambda=\frac{L_{\text {model }}}{L_{\text {prototye }}}\right)$ and Froude number/modified Froude number, the parameters are first converted to dimensionless patterns. Then, their dimensionless expressions are mathematically correlated. Previous work in this area is listed in Table VI. For gas injection scaling, ${ }^{[69]}$ the ratio of the inertial and buoyancy forces in the plume are considered to achieve flow similarity. In several works, ${ }^{[21,24,70]}$ the relationships between parameters, such as the gas flow rate and mixing time for laboratory scale models, prototypes, and industrial scale ladles, have been analyzed. In a recent work of Krishnapisharody and Irons, ${ }^{[3]}$ they compared calculated and experimental data, and the modified Froude number was derived. They reported that the buoyancy of the plume more useful than the momentum of the injected gas in description of the hydrodynamics in the two-phase plume zone. Moreover, various fluid properties, such as liquid density and surface tension, have been added to the modified scaling criteria to improve the scaling criterion. ${ }^{[3,4,68]}$

\section{NUMERICAL MODELS TO STUDY THE GAS-LIQUID ZONE IN LADLE REFINING}

\section{A. Multiphase Models Applied to Study Ladle Refining}

To describe gas-liquid two-phase flow, there are four main mathematical methods: (1) the quasi-single-phase model, (2) the volume of fluid (VOF) model, (3) the Eulerian multiphase (E-E) model, and (4) the Eulerian-Lagrangian (E-L) model. In early works, the plume zone mixed with gas and liquid was treated as a quasi-single-phase. With the increase in computational capabilities, the VOF and the E-E models have become widely used for the simulation of the interphase interactions of the gas and liquid phases. In comparison to the predictive quasi-single-phase model, the VOF and the $\mathrm{E}-\mathrm{E}$ models are more computationally expensive. Recently, commercial codes coupled with user-defined functions (UDFs) have been widely employed for the study of gas bubbling in ladles. In recent years, a new approach $^{[39]}$ to calculate the gas bubble size distribution within the $\mathrm{E}-\mathrm{E}$ model based on the population balance model (PBM) has been proposed. In the $\mathrm{E}-\mathrm{L}$ model, ${ }^{[71-73]}$ the VOF model is used to track the free surface of the melt coupled in Eulerian coordinates, whereas the discrete phase model (DPM) is used to describe the stirring generated by the bubbles under a Lagrangian reference frame. Some previous works ${ }^{[74-76]}$ have compared the quasi-single-phase model, VOF model, E-E model, and E-L model, and these comparisons reveal that the advanced models have gradually improved in the last few years.

\section{Quasi-single-phase model}

The quasi-single-phase model is the simplest of the four models discussed previously. The quasi-single-phase model avoids the need to compute the motion of the bubbles. The key principal in this model is that the characteristics of the plume, such as the gas fraction, velocity pattern, and plume diameter, are set using empirical equations. Thus, the volume fraction equation is not coupled to the equation group to be solved. A buoyancy term generated by the gas bubbling is added into the momentum conservation equation. In this model, the plume is treated as a quasi-single phase in which the volume fraction of gas in each control volume is affected by various parameters during calculation.

In the quasi-single-phase model, the equations of continuity and momentum are written as follows.

Continuity equation:

$$
\frac{\partial \rho}{\partial t}+\nabla \cdot(\rho \vec{u})=0
$$




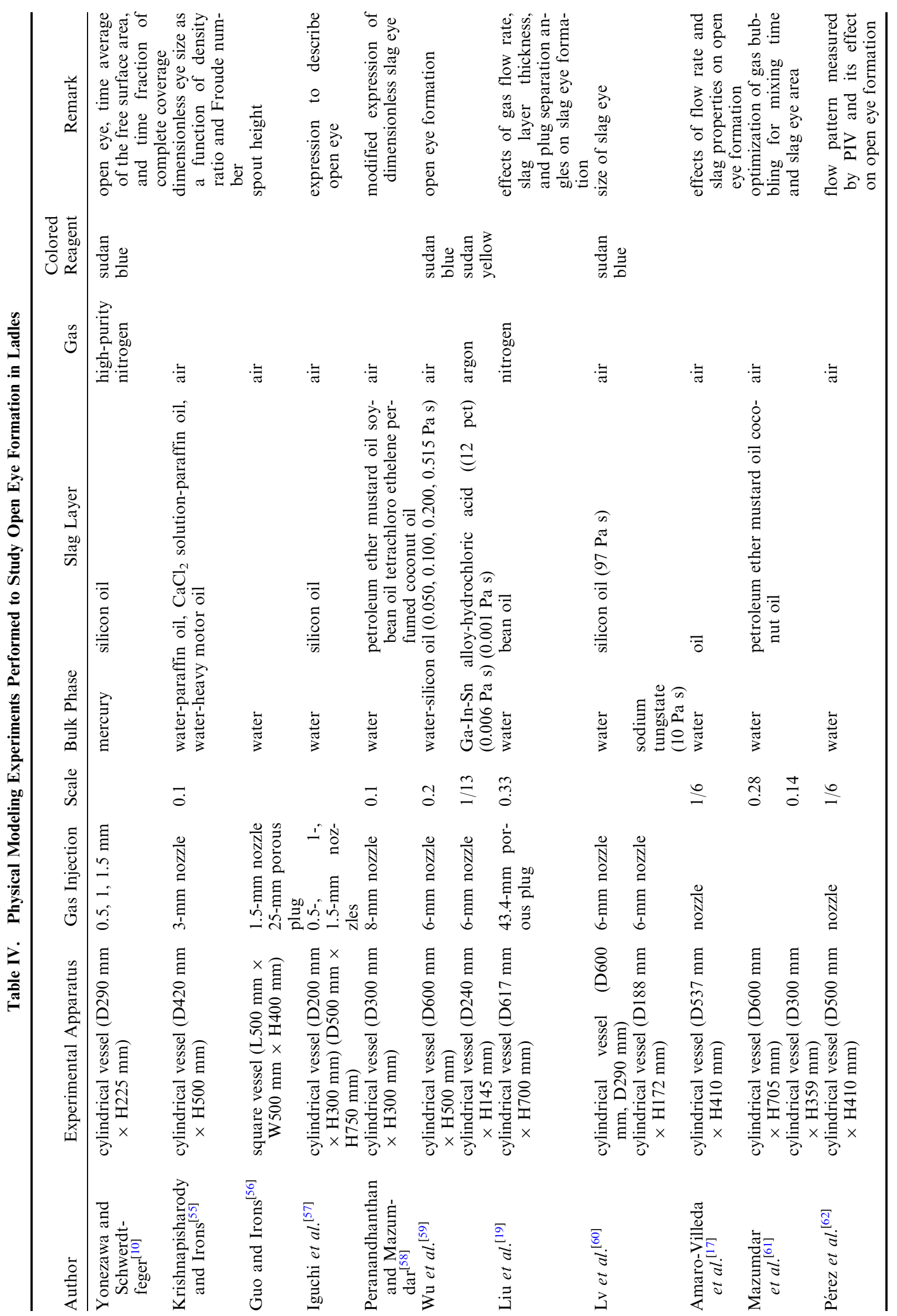




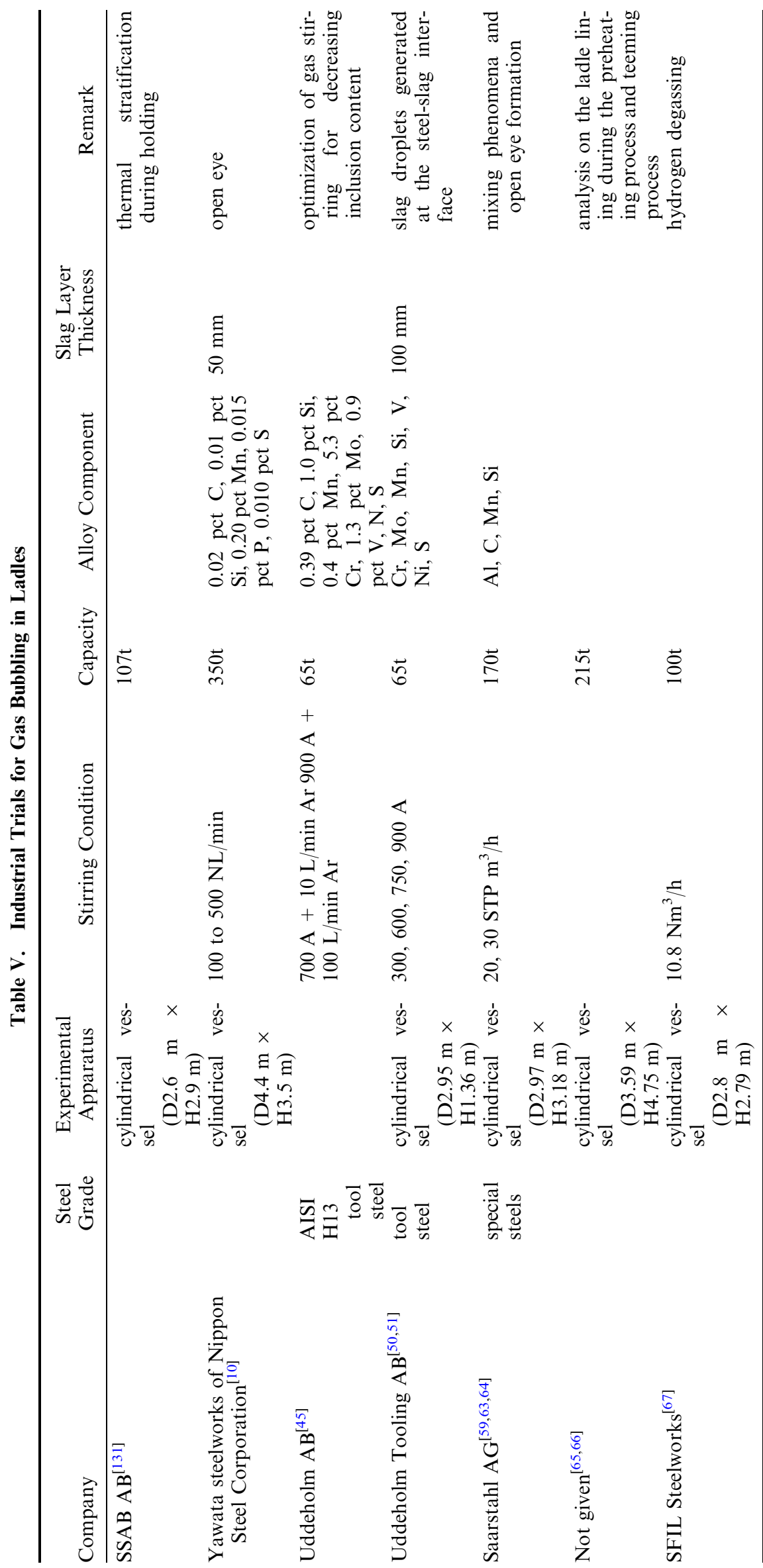




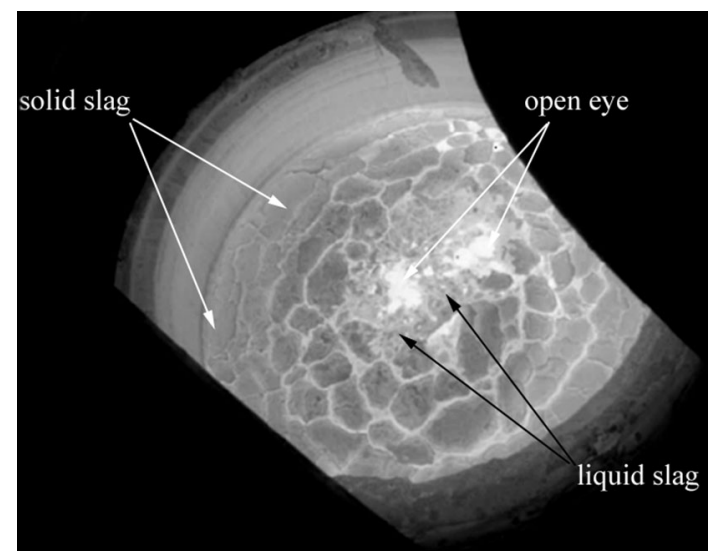

Fig. 4-Molten slag and open eye formation in an industrial ladle.

Momentum equation:

The density in the plume is $\rho=\alpha_{\mathrm{g}} \rho_{\mathrm{g}}+\alpha_{1} \rho_{1}$, and the recirculation zone is treated as a liquid phase $\rho=\rho_{1}$.

For the plume zone, several different parameter expressions have been developed, as shown in Table VII. The quasi-single-phase model has been used mainly to predict the flow pattern in the ladle because this model has low computational expense. Sahai and Guthrie $^{[9,77]}$ and Mazumdar ${ }^{[78]}$ introduced an effective viscosity model to describe the circulatory flow and the hydrodynamic phenomena in the plume when using central gas injection. Based on the previous work ${ }^{[9,77]}$ they initially set up a quasi-single-phase model $^{[79]}$ in axisymmetric coordinates. Furthermore, using this model, Joo and Guthrie ${ }^{[8]}$ and Mazumdar and Guthrie $^{[80]}$ considered the effects of different ladle operations, such as the tapered side walls, surface baffles, and plug configurations, on the flow pattern and mixing mechanisms. Later, Mazumdar et al. ${ }^{[81]}$ proposed a new equation to estimate the average velocity of the rising plume of the gas-liquid mixture and reported a model with slip (rather than with no slip) between the gas phase and the liquid phase to provide a more realistic description of the actual physical phenomenon. Furthermore, Madan et al. ${ }^{[75]}$ compared the mixing conditions in a dual-plug ladle calculated by the quasi-single-phase model and the E-L model. In contrast to previous quasi-single-phase models in cylindrical coordinates, Goldschmit and Owen ${ }^{[82]}$ also constructed their calculation system in Cartesian coordinates to study the effect of different separation angles and positions of the porous plugs on the flow pattern. In addition, Ganguly and Chakraborty ${ }^{[83]}$ coupled the thermal energy equation with the quasi-single-phase model to study the fluid flow and heat transfer in the gas-stirred ladle. The combined model aimed to control the thermal stratification in the molten steel. A

$$
\begin{aligned}
\frac{\partial}{\partial t}(\rho \vec{u})+\rho \vec{u} \cdot \nabla \vec{u}= & -\nabla p+\nabla \cdot\left[\left(\mu+\mu_{\mathrm{t}}\right)\left(\nabla \vec{u}+\nabla \vec{u}^{T}\right)\right] \\
& +\rho_{1} \vec{g} \alpha_{\mathrm{g}}
\end{aligned}
$$

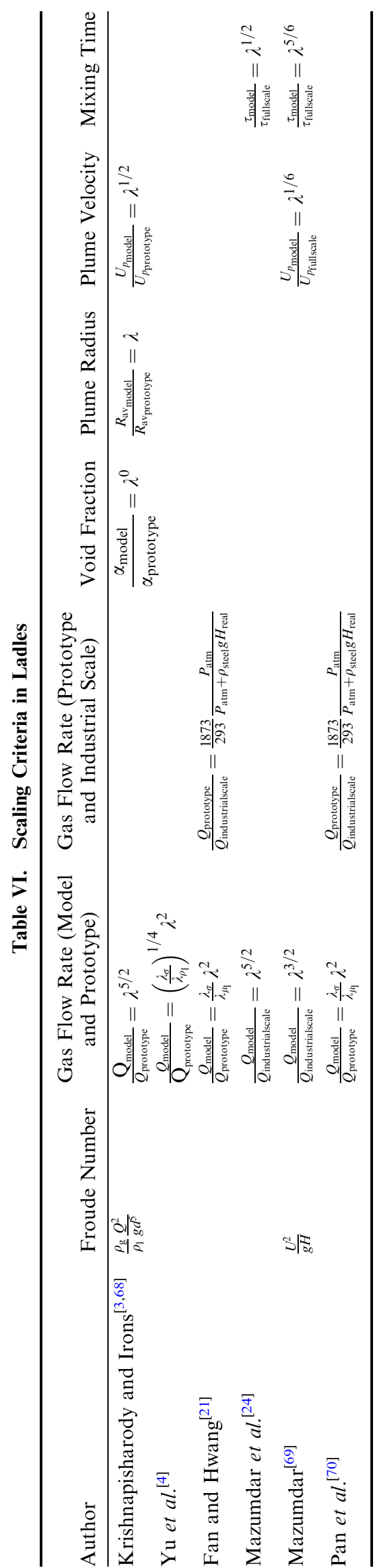

METALLURGICAL AND MATERIALS TRANSACTIONS B 


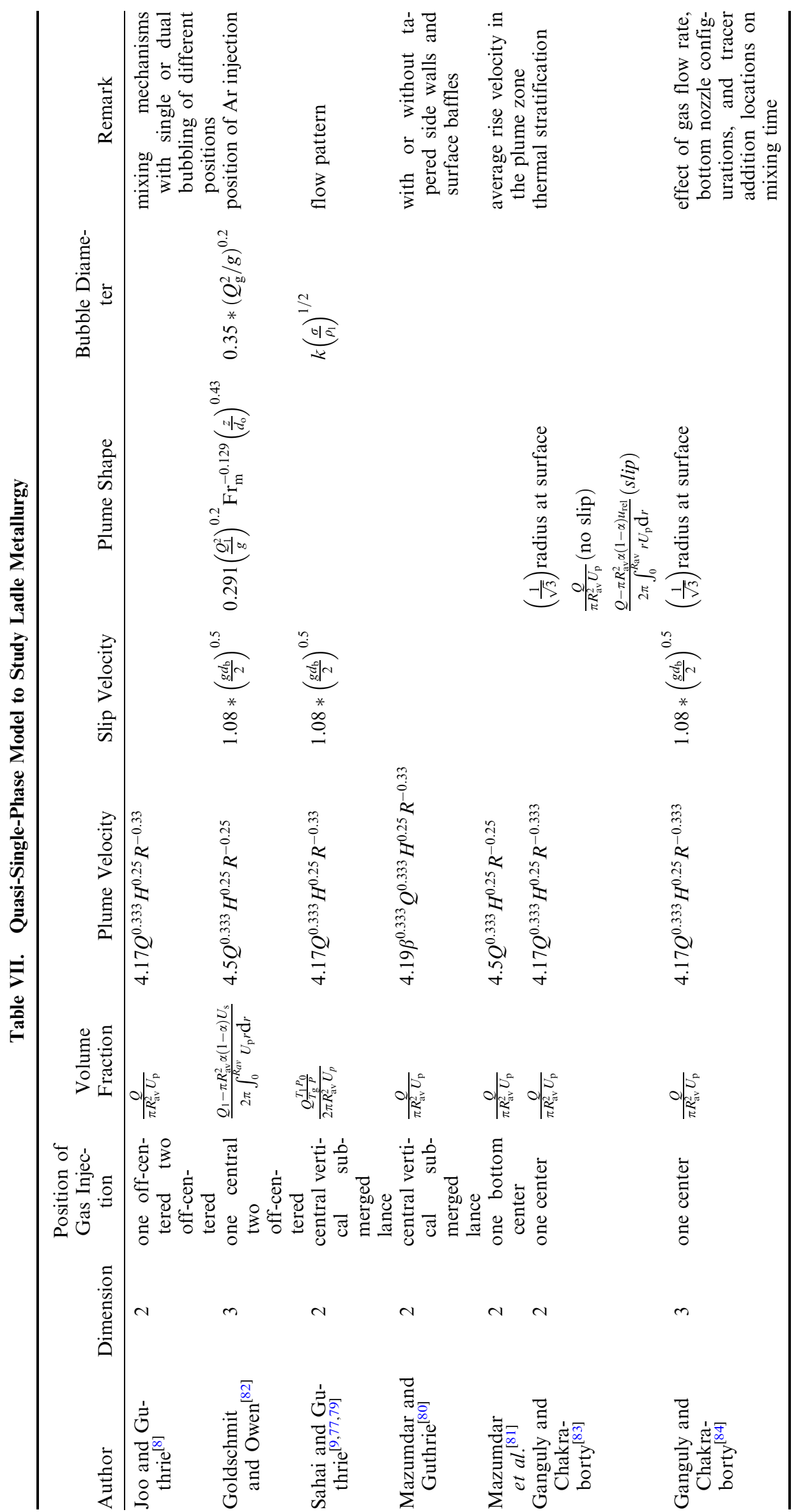


quasi-single-phase model based on slippage and no slippage between the rising bubbles and the surrounding liquid was also set up by the same research group. ${ }^{[84]}$ Compared with the experimental velocities and mixing time data, the numerical calculation with slippage showed a higher accuracy than that without a slippage for predicting the flow pattern.

\section{VOF model}

The VOF model is widely used to track the interfaces of different phases and is a type of Eulerian method. When the flow rate is low, separate bubbles are generated and the interfaces of the different phases are sharp. As the flow rate increases, the gas injection leads to the plume transferring from a bubble regime to a jetting regime. ${ }^{[40]}$ In the VOF model, one set of equations for continuity, momentum, and phase volume fraction is calculated. The conservation formulas are shown as follows.

Continuity equation:

$$
\frac{\partial \rho}{\partial t}+\nabla \cdot(\rho \vec{u})=0
$$

Momentum equation:

$$
\begin{aligned}
\frac{\partial}{\partial t}(\rho \vec{u})+\nabla \cdot(\rho \vec{u} \vec{u})= & -\nabla p+\nabla \cdot\left[\left(\mu+\mu_{\mathrm{t}}\right)\left(\nabla \vec{u}+\nabla \vec{u}^{T}\right)\right] \\
& +\rho \vec{g}+F_{\mathrm{S}}
\end{aligned}
$$

Volume fraction:

$$
\begin{gathered}
\frac{\partial \alpha_{q}}{\partial t}+\vec{u} \cdot \nabla \alpha_{q}=0 \\
\sum \alpha_{q}=1
\end{gathered}
$$

( $q$ is the fluid phase, e.g., liquid and gas)

Continuum surface force model:

$$
F_{\mathrm{s}}=\sigma \frac{\rho \kappa \nabla \alpha_{1}}{0.5\left(\rho_{1}+\rho_{\mathrm{g}}\right)}, \kappa=\nabla \cdot \hat{n}, \hat{n}=\frac{\vec{n}}{|\vec{n}|}, \vec{n}=\nabla \alpha_{\mathrm{g}}
$$

Previous works of the use of the VOF model in ladle metallurgy are summarized in Table VIII. Because of the ability of the VOF model to track the sharp interface, this model has been used in three main analysis points: for modeling the gas-liquid phase interfaces, coupled with the DPM, and coupled with thermodynamic models. Xu et al. ${ }^{[40,85]}$ considered the surface force in the VOF model to investigate a single bubble rising in molten steel and bursting at the interface. Furthermore, the effect of the wettability on single bubble formation was reported based on VOF model predictions and water model experiments. Wang et al. ${ }^{[41]}$ extended single bubble formation and rising to coaxial bubble coalescence and parallel bubble bouncing. Li et al. ${ }^{[86]}$ used the multiphase VOF model to simulate the flow pattern and the interface behavior of the molten steel and slag layer. The effects of the gas flow rate and nozzle arrangement were the focus in their work. The VOF model was employed by Llanos et $a .^{[11]}$ to study the influence of various gas injection arrangements on the mixing time, the wall skin friction coefficient, and the open eye area. Compared with the use of one argon injection tuyere, the use of two argon injection tuyeres showed no obvious reduction in the mixing time. However, the slag layer opening and the skin friction coefficient value decreased. In a recent work by Ramasetti et al. ${ }^{[87]}$ the same method was also used to predict open eye formation. In the work of Huang et al. ${ }^{[49]}$ the VOF model and the large eddy simulation (LES) model were used to analyze slag droplet entrainment in the open eye zone. The model was then modified using a UDF by $\mathrm{Li}^{[88]}$ yielding a new method to track the number of droplets, as well as the volume and location of every droplet in the domain. A similar model was also developed by Sulasalmi et al. ${ }^{[89,90]}$ to analyze the effect of the interfacial velocity on droplet distribution and slag emulsifications at the steel-slag interface. In the research of Senguttuvan ${ }^{[91]}$ and Senguttuvan and Irons, ${ }^{[92]}$ the entrainment of slag into molten metal and vice versa was modeled by using a coupled VOF-LES model. The relationship between the amounts of entrained slag and the interfacial mass transfer rate was discussed. Depending on the research characteristics, not only the VOF model could be used to track the interface of different phases, but also other improved models could be used to study the inclusion behavior in molten steel. Based on the preliminary work, a coupled model was employed by $\mathrm{Xu}$ et $a l^{[93]}$ to study the effect of wake flow on inclusion removal. In their work, the VOF model was used to calculate the fluid dynamics induced by single bubbles and the DPM was used to track the motion of the particles. Some researchers have also made efforts to combine fluid dynamics and thermodynamics calculations. Ersson et $a .^{[94]}$ developed a coupled model, combining the VOF model and the Thermo-Calc software database, to compute the fluid dynamics and thermodynamics simultaneously. They investigated the interfacial decarburization in a top blown converter. Later, Singh et al.$^{[95]}$ used the same method to model the desulfurization process around the open eye area, as well as at the steel-slag interface. However, concerning bubble behavior under vacuum conditions, only a few works using mathematical modeling have been reported.

\section{E-E model}

In the E-E model, multiple sets of equations for the continuity, momentum, turbulent energy, and dissipation rate are calculated for each phase. This increased complexity affects the convergence behavior. ${ }^{[96,97]} \mathrm{E}-\mathrm{E}$ models can be used to include the effects of forces, such as the virtual mass force, drag force, lift force, and turbulent dissipation force, on the flow pattern. In practice, the relatively complex $\mathrm{E}-\mathrm{E}$ model is mostly used. Based on this model, ${ }^{[4,48,98-100]}$ a coupling with the PBM has been developed to simulate the subsize bubble behavior generated from a porous plug in the plume zone. ${ }^{[39]}$ In this model, conservation equations are solved. 


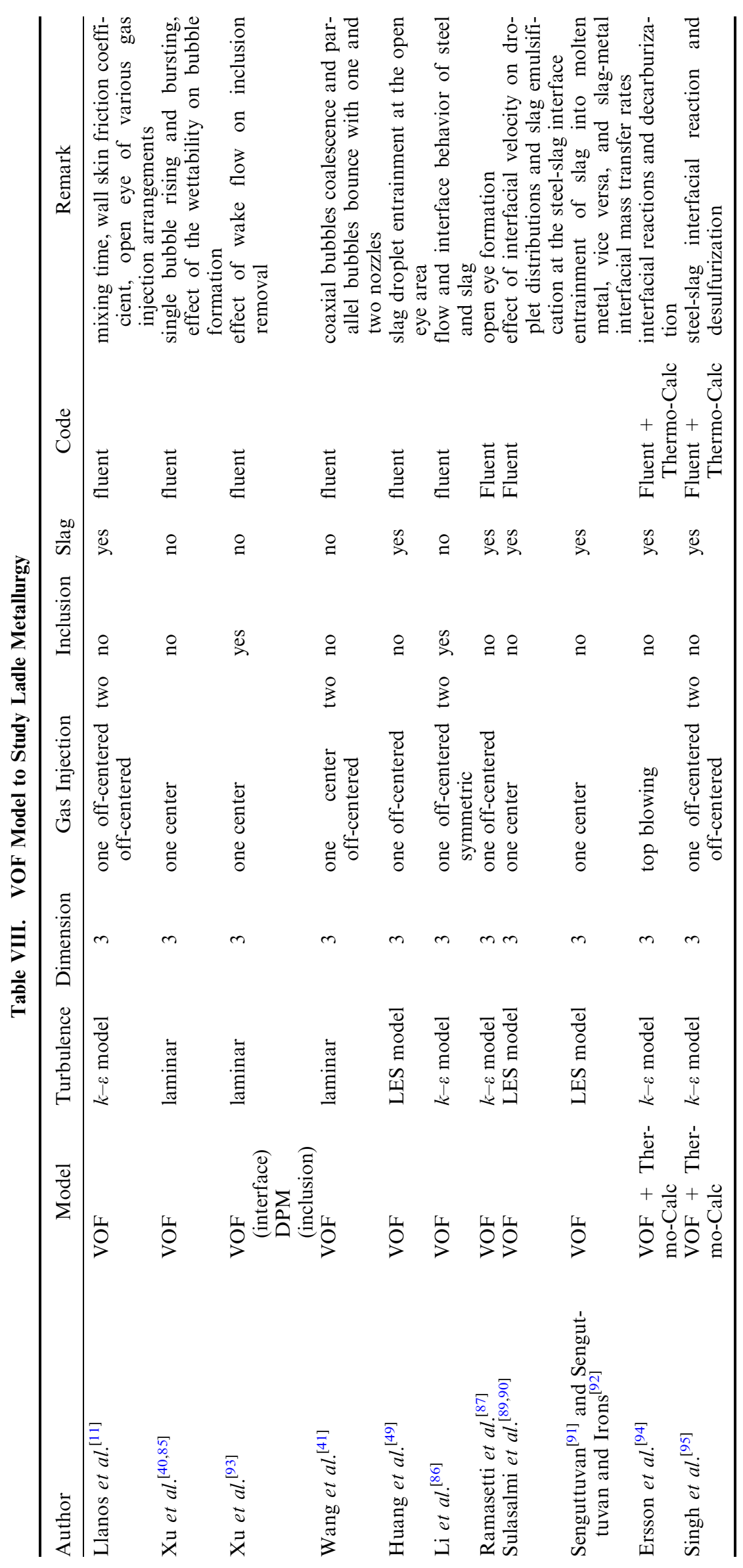


Continuity equation:

$$
\frac{\partial}{\partial t}\left(\alpha_{q} \rho_{q}\right)+\nabla \cdot\left(\alpha_{q} \rho_{q} \vec{u}_{q}\right)=S_{q}
$$

( $q=l$ is the equation for the liquid phase, $q=g$ is the equation for the gas phase, and $q=p$ is the equation for the particle)

Momentum equation:

$$
\begin{aligned}
\frac{\partial}{\partial t}\left(\alpha_{q} \rho_{q} \vec{u}_{q}\right)+\nabla \cdot\left(\alpha_{q} \rho_{q} \vec{u}_{q} \vec{u}_{q}\right) \\
=-\alpha_{q} \nabla p+\nabla \cdot \bar{\tau}_{q}+\alpha_{q} \rho_{q} \vec{g}+\vec{F}_{\mathrm{drag}, q}+\vec{F}_{\mathrm{lift}, q}+\vec{F}_{\mathrm{VM}, q} \\
\quad+\vec{F}_{\mathrm{TD}, q}
\end{aligned}
$$

PBM for the description of bubble behavior:

Transport equation:

$$
\begin{aligned}
\frac{\partial}{\partial t}(n(V, t))+\nabla \cdot\left(\vec{u}_{\mathrm{i}} n(V, t)\right)= & B_{\mathrm{ag}, \mathrm{i}}-D_{\mathrm{ag}, \mathrm{i}}+B_{\mathrm{br}, \mathrm{i}} \\
& -D_{\mathrm{br}, \mathrm{i}}
\end{aligned}
$$

Studies using E-E models to explore ladle metallurgy are summarized in Table IX. The E-E model in commercial packages or research codes has been employed to analyze the inclusion behavior and complex chemical reactions in gas-stirred ladles. Jönsson et al. ${ }^{[46,101,102]}$ and Söder ${ }^{[103]}$ developed a model to investigate the inclusion behavior in gas-stirred ladles with the PHOENICS code. In this code, the interphase slip algorithm, originally developed by Spalding et al., ${ }^{[104,105]}$ was used to solve the two-phase problem. Based on the same fluid dynamics code, they ${ }^{[106-108]}$ also combined fluid dynamics and thermodynamics to study the flow pattern and chemical reactions around the steel-slag interface. At the same time, several forces in the E-E model ${ }^{[109,110]}$ were analyzed by using the CFX code to predict the flow pattern in ladle furnaces. In addition, Wang et al. ${ }^{[111,112]}$ used the CFX code to investigate three mechanisms of inclusion collisions, that is, Brownian collision, turbulent collision, and Stokes collision, and two main mechanisms of inclusion removal, that is, Stokes flotation and bubble adhesion. Geng et al. ${ }^{[113]}$ also used the CFX code to study the effect of the dual-plug separation angle and axial distance on the mixing time. Moreover, Maldonado-Parra et al. ${ }^{[114]}$ studied the effects of the radial position of single plug and dual plugs on mixing time using the PHOENICS code. In recent works by De Felice et al. ${ }^{[99]}$ and Bellot et al., ${ }^{[100]}$ the PBM coupled with the traditional E-E model was employed to study the inclusion transport, aggregation, and surface entrapment in the gas-stirred ladle. Huang et al. ${ }^{[115]}$ also used the E-E model to calculate two-phase flow and the DPM to predict inclusion trajectories and to describe the effects of purging plug arrangement and gas flow rate on the erosion of the lining of the refining ladle. Lou and $\mathrm{Zhu}^{[47,48,96,116,117]}$ have made step-by-step contributions to the numerical simulation of the ladle process. In the first step, they ${ }^{[96]}$ investigated the effects of the turbulent dissipation force, bubble-induced turbulence, drag force, lift force, and bubble size on the profile of the plume. In the next step, they combined the PBM and the E-E model developed in their previous work ${ }^{[96]}$ and used to investigate the various mechanisms of inclusion growth and removal under different tuyere conditions. ${ }^{[47,48]}$ In the last step, ${ }^{[116,117]}$ the calculations of the thermodynamics and fluid dynamics in a gas-stirred ladle were used to describe the efficiencies of desulfurization, dealumination, desilication, and demanganization. Based on previous work on the E-E model, the simultaneous reaction model (SRM) coded by these researchers was added to investigate the metal-slag reactions. In contrast, Yu et al. ${ }^{\left[11^{-122]}\right.}$ mainly focused on investigating the dehydrogenation and denitrogenation behaviors in an industrial vacuum tank degasser with different operating conditions. A recent work by $\mathrm{Li}$ et al. ${ }^{[39]}$ used the PBM to calculate the bubble size distribution affected by the coalescence and breakage in the plume. Based on the E-E model, studies on the combination of fluid dynamics and thermodynamics, such as desulfurization, need to be developed further.

\section{E-L model}

In the DPM, forces, such as the virtual mass, buoyancy, drag force, lift force, and pressure gradient, are added to each bubble particle. The momentum source term is added to the continuous phase momentum equation by summing the local contributions from each bubble in the continuous phase flow field: ${ }^{[72]}$

$$
\begin{aligned}
F_{\mathrm{bi}} & =\sum_{1}^{N_{\mathrm{b}}}\left(F_{\mathrm{Di}}\left(\vec{u}_{\mathrm{i}}-\vec{u}_{\mathrm{bi}}\right)+\frac{\rho_{\mathrm{b}}-\rho}{\rho_{\mathrm{b}}} \vec{g}+\frac{1}{2} \frac{\rho}{\rho_{\mathrm{b}}} \frac{d}{d t}\left(\vec{u}_{\mathrm{i}}-\vec{u}_{\mathrm{bi}}\right)\right. \\
& \left.+\frac{\rho}{\rho_{\mathrm{b}}} \vec{u}_{\mathrm{i}} \cdot \nabla \vec{u}_{\mathrm{i}}\right) \rho_{\mathrm{b}} Q_{\mathrm{bi}} \Delta t
\end{aligned}
$$

Studies of using the E-L model applied on ladle metallurgy are summarized in Table X. Initially, an E-L model was developed in the commercial package ANSYS FLUENT ${ }^{\circledR}$ by Aoki et al. ${ }^{[123]}$ They used this model to study how the bubble morphology affects the probability of inclusion attachment. The interaction forces on the liquid-gas plume were taken into consideration in the calculations. In addition, Singh et al. ${ }^{[124]}$ used a similar model and improved the grid resolution near the wall to investigate the wall shear stress distribution in a gas agitated vessel. Because of the limitations of the E-E model, particle tracking using the DPM in the E-E model showed flow field interacts only with the primary phase. Therefore, Cloete et al. ${ }^{[71]}$ replaced the E-E model with the VOF model for tracking of the melt interface, wherein the DPM was used to calculate the trajectory of each bubble. In addition, Liu et al. ${ }^{[72]}$ used a similar model to predict the interface behaviors and the mixing times of one-plug and dual-plug systems with the plugs placed 90 and 180 deg apart. As a result, an arrangement of the dual-plug system having a separation angle of $180 \mathrm{deg}$ at low gas flow rates was recommended for inclusion removal. The same method was also employed by $\mathrm{Li}$ et al. ${ }^{[73]}$ for studying alloy dispersions. Using the $\mathrm{E}-\mathrm{L}$ model with 


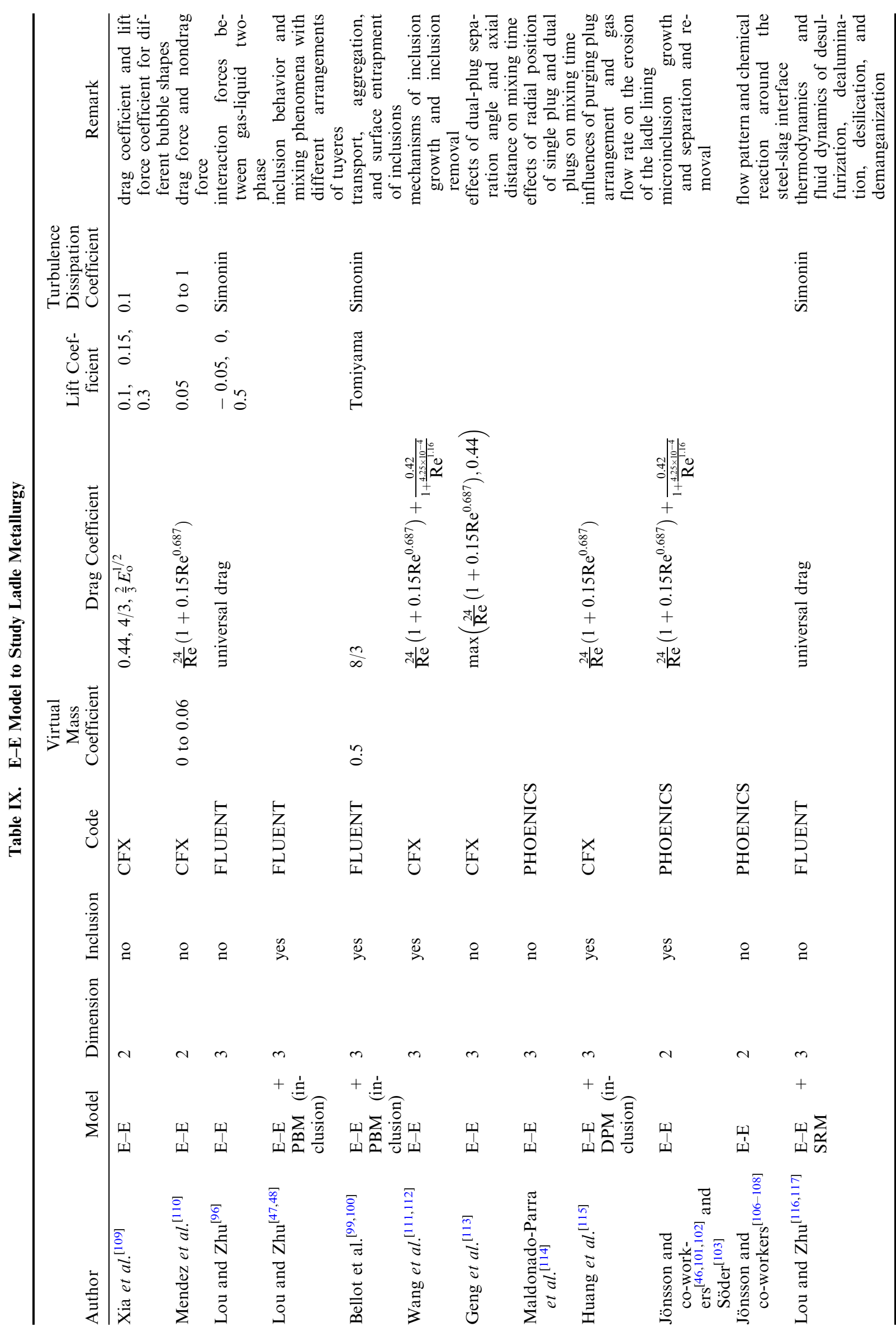




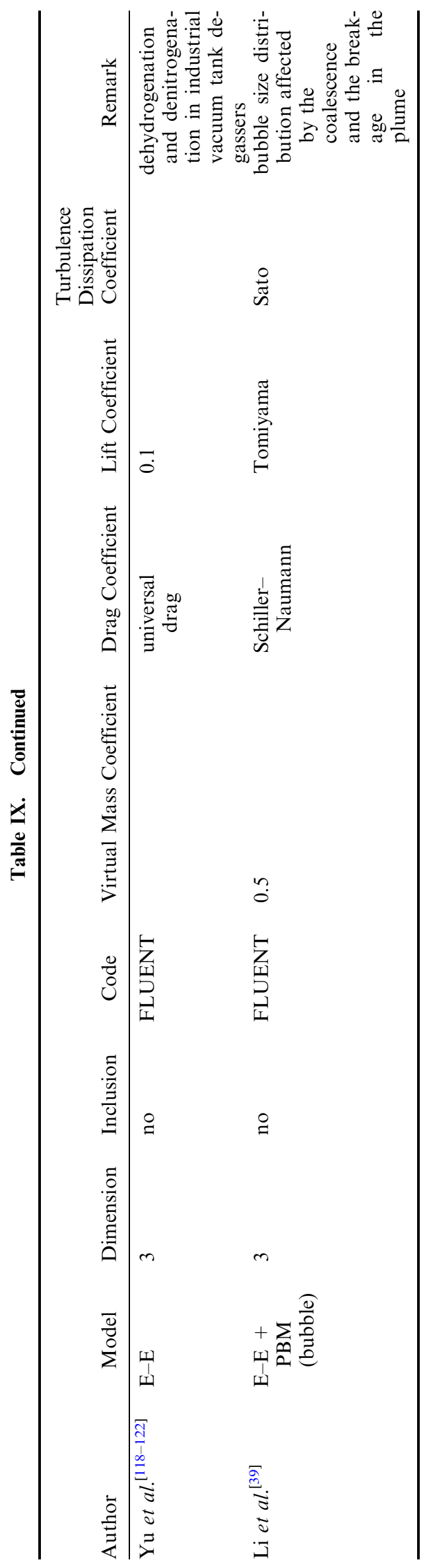

the consideration of bubble aggregation, Li et al. ${ }^{[125,126]}$ added the LES model to calculate the multiscale eddies and study the unsteady state of the open eye.

\section{B. Turbulence Models Applied in Ladle Refining}

Concerning turbulence models applied in the mathematical modeling of ladle metallurgy, two kinds of turbulence models, namely, the $k-\varepsilon$ model and LES model, have been widely used. The standard $k-\varepsilon$ model is most commonly used for the calculation of the flow pattern in industrial ladles. In some works, the standard $k-\varepsilon$ model ${ }^{[96]}$ modified with bubble-induced turbulence and the renormalization (RNG) $k-\varepsilon$ mode $^{[39]}$ have also been employed. Compared with the standard $k-\varepsilon$ model, the form of the RNG $k-\varepsilon$ model is similar but has an additional term that improves the accuracy for rapidly strained flows and enhances the accuracy for swirling flows. The $k-\varepsilon$ model is a Reynolds averaged numerical simulation (RANS), which averages the numerical information of eddies with various sizes. However, in the LES model, the large and small eddies are treated separately in the calculations. The large eddies are resolved directly and the small eddies are calculated by the Smagorinsky-Lilly subgrid-scale model. Here, the LES model can be seen as a compromise between direct numerical simulation and the RANS model in terms of accuracy and computational cost. With the development of computational abilities, the LES model ${ }^{[49,125,127]}$ has become increasingly used to predict the slag entrapment and bubble distribution in the modeling of metallurgical systems.

\section{Comparison of Calculation Systems}

Based on the basic fundamental theory and applicability of each model, four main models have been used in different research areas. A comparison of the momentum equations and turbulence models employed in different areas are listed in Table XI. For analysis of the separate bubbles and slag eye opening, the VOF model has mainly been used, allowing the sharp interfaces of different phases to be tracked. In addition, the quasi-single-phase model, E-E model, and E-L model have been widely used to calculate the flow patterns in industrial metallurgical ladles. The main difference among these three models is how the gas-liquid interactions are treated. The expressions for gas-liquid interactions in the numerical models are the forces added to the momentum equation. The predicted axial liquid velocity along the radial direction at $L / H=0.5$ from the bottom under the same conditions in the quasi-single-phase model, ${ }^{[82]} \mathrm{E}-\mathrm{E}$ model,${ }^{[96]}$ and $\mathrm{E}-\mathrm{L}$ model $^{[31]}$ are compared with the measured data ${ }^{[31]}$ in Figure 5 (for detailed experimental conditions, see Reference 31). The quasi-single-phase model is the simplest one of the three models. In this model, the shape of the two-phase zone is predicted in advance, so this model cannot predict the flow pattern of circulation in the ladle accurately. However, on reviewing the principles of this model, the relationship between various parameters is deeply distinct. The E-E model 


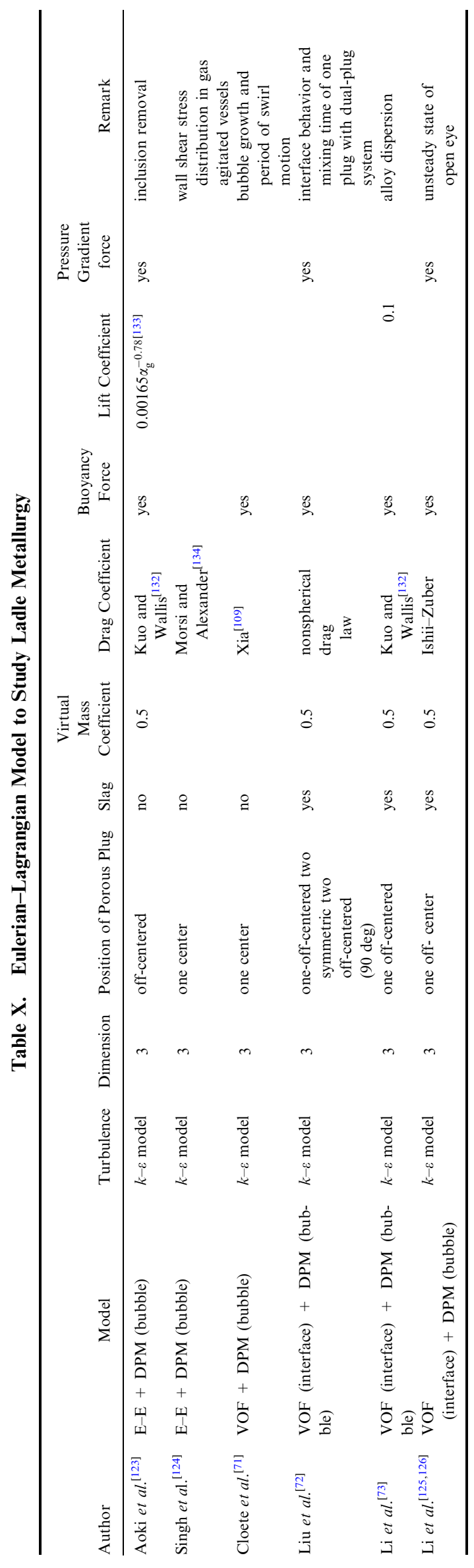

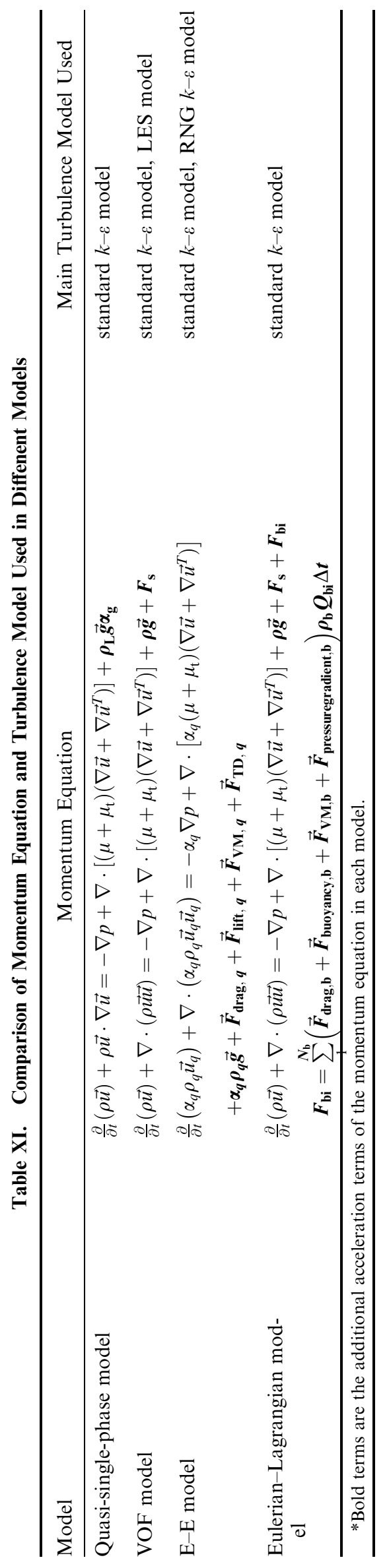

METALLURGICAL AND MATERIALS TRANSACTIONS B 
is most consistent with the experimental results, and the $\mathrm{E}-\mathrm{L}$ model is the second-best option. Because of the high volume fraction in the primary zone, the $\mathrm{E}-\mathrm{E}$ model is more accurate in describing the phenomena in this zone. With respect to the axial distance from the nozzle exit and the transformation of bubbles in the plume, the DPM is more suitable for the prediction of the bubble behavior at the bubble buoyancy zone and spout zone. Modifying the drag coefficient and adding nondrag forces improves the $\mathrm{E}-\mathrm{E}$ model considerably. In recent studies of ladle metallurgy, based on the modified $\mathrm{E}-\mathrm{E}$ model of the gas stirring conditions, a

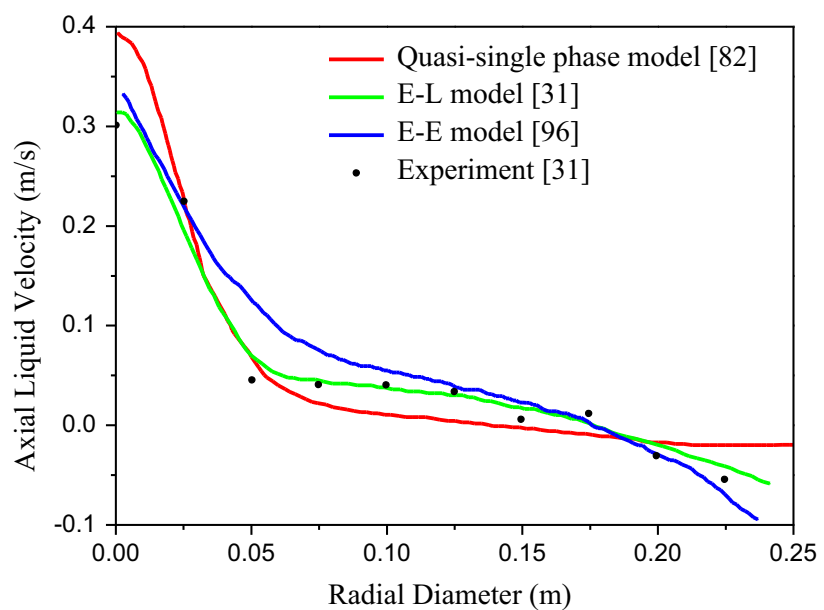

Fig. 5-Comparison of predicted and measured axial liquid velocities along the radial direction at $L / H=0.5$ from the bottom under the same conditions. large number of special models, either in commercial packages or research codes, have been coupled together to describe the complex physical and chemical phenomena in the ladle. This includes inclusion behavior, degassing, refractory erosion, and thermodynamic reactions. The different research directions can be classified by the different locations in the ladle and the preferred combinations of the numerical models, as shown in Figure 6. In general, several types of mathematical model have been studied in ladle refining: (1) velocity distribution and turbulent dissipation; (2) alloy and temperature homogenization (mixing time); (3) number, location, and pattern of plugs; (4) bubble behavior in the plume zone; (5) open eye formation; (6) slag entrapment and inclusion behavior at the steel-slag interface; (7) inclusion removal in molten steel; (8) vacuum degassing; and (9) the combination of fluid dynamics and thermodynamics for interface reactions. Furthermore, based on the analysis of previous studies, both the PBM and DPM have been used to describe the movement and interaction inclusion particles and bubbles in advanced models. In conclusion, many physical and mathematical models have been developed to investigate alloy homogenization and open eye formation. However, in terms of the physical and mathematical modeling of the mass transfer phenomenon, there are only a few works studying the steel-slag interface reactions, ${ }^{[76,92]}$ vacuum degassing at the gas-liquid interface, ${ }^{[28,37,43,128]}$ and dissolution rate of the solid alloy at the liquid-solid interface. ${ }^{[73,123,129]}$ For the inclusion behavior at the steel-slag interface, physical ${ }^{[50,51,53,54,130]}$ and mathematical models ${ }^{[49,89-91]}$ have been developed, but the interactions of the slag layer phase and inclusion particles need to be improved to study the droplet behavior at the

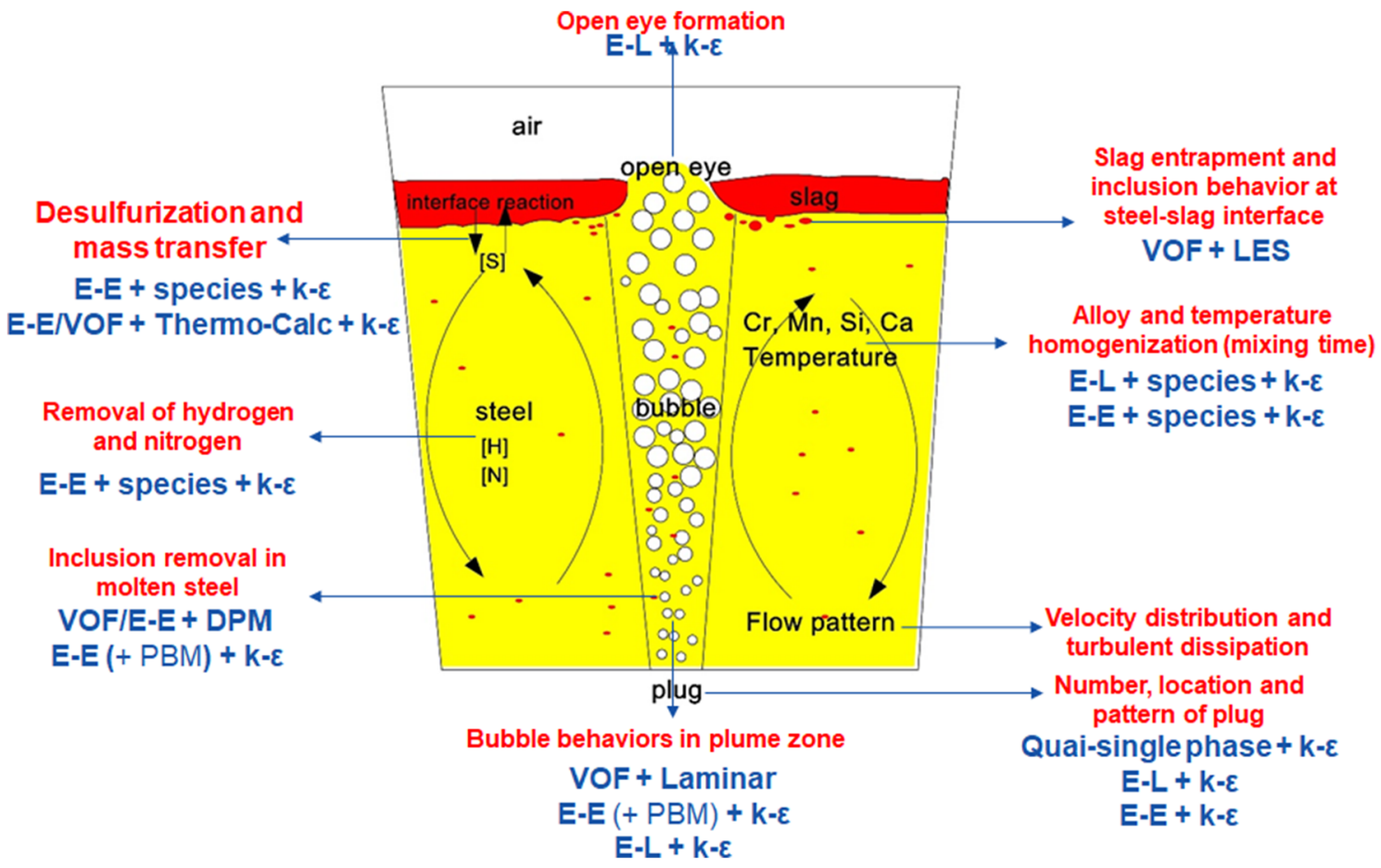

Fig. 6-Schematic diagram of preferred numerical models in different research areas in ladle metallurgy. 
interface. Moreover, the existing combined analysis of the combination of fluid dynamics and thermodynamics $^{[94,95,107,108,116]}$ is not sufficient and needs to be improved further. On the whole, none of these mathematical models functions well in all research aspects and each has its own limitations. To better describe industrial conditions using mathematical methods and to improve numerical modeling, the results of physical modeling experiments and industrial trials must offer satisfactory validations.

\section{CONCLUDING REMARKS}

In the present article, many of the investigations into ladle metallurgy reported over the past few decades have been reviewed. Although not all research has been covered, several typical works and methods have been summarized. Some conclusions are given and works needing improvement are suggested as follows.

1. Depending on the research goal, previous physical modeling experiments in the lab scale have been divided based on four major research focuses: (a) mixing and homogenization in the ladle, (b) gas bubble formation, transformation, and interactions in the plume zone; (c) inclusion behavior; and (d) steel-slag interface and open eye formation. Several industrial trials have focused on open eye formation and the optimization of gas stirring. Concerning physical modeling, such as mixing and homogenization in ladles, the general empirical rules have not been analyzed sufficiently.

2. The connection between industrial trials and physical modeling experiments is important for determining scaling criteria. Froude similarity and modified Froude similarity seem to be the most common dimensionless numbers used in gas-stirred metallurgical reactors. The parameters of the water model, prototype, and industrial ladles (that is, the gas flow rate, void fraction, plume radius, plume velocity, and mixing time) are directly linked by the ratios of geometric factors, or transferred to dimensionless patterns first and then mathematically related.

3. According to the basic fundamental theory and applicability of each model, four kinds of multiphase models coupled with three kinds of turbulence models, particularly paying attention to different research directions, have been discussed. The VOF model is mainly used to track the sharp interfaces of different phases for the analysis of bubble separation and slag eye opening. The quasi-single-phase model, E-E model, and Eulerian-Lagrangian model have been widely used to calculate the flow patterns in industrial metallurgical ladles. In the three mathematical models, the set of equations for the main liquid phase are solved using a Eulerian algorithm. The difference between the three models is the method used to describe the liquid-gas two-phase zone. Based on the modified E-E model for the gas stirring conditions, a large number of special models in commercial packages or research codes have been coupled to describe the complex physical and chemical phenomena in the ladle. This includes inclusion behavior, degassing, refractory erosion, alloy homogenization, and thermodynamic reactions. For the turbulence models, the $k-\varepsilon$ model is commonly used for the calculation of the flow pattern in industrial ladles, and the LES model has become increasingly used in the study of metallurgical systems.

4. Based on the present review, the following recommendations regarding model combinations are suggested: (a) for physical modeling, such as mixing and homogenization in ladles, the general empirical rules have not been analyzed sufficiently; (b) the mathematical models focusing on inclusion behaviors at the steel-slag interface need to be improved; and (c) the phenomena governing the transfer of elements, vacuum degassing, and the combination of fluid dynamics and thermodynamics, such as in desulfurization, need to be developed further.

\section{ACKNOWLEDGMENTS}

One of the authors (YL) extends his sincere appreciation to the China Scholarship Council for financial support of his study at the KTH-Royal Institute of Technology (Stockholm).

\section{OPEN ACCESS}

This article is distributed under the terms of the Creative Commons Attribution 4.0 International License (http://creativecommons.org/licenses/by/4.0/), which permits unrestricted use, distribution, and reproduction in any medium, provided you give appropriate credit to the original author(s) and the source, provide a link to the Creative Commons license, and indicate if changes were made.

\section{VARIABLES}

$\lambda, \lambda_{\rho_{1}}, \lambda_{\rho_{\mathrm{g}}}, \lambda_{\mu_{1}}, \lambda_{\sigma} \quad$ Geometric ratio of scaling criterion, liquid density ratio of scaling criterion, gas density ratio of scaling criterion, viscosity ratio of scaling criterion, and surface tension ratio of scaling criterion $\beta$

$d_{\mathrm{b}} \quad$ Bubble diameter (m)

$H \quad$ Liquid depth (m)

$d \quad$ Inner nozzle diameter $(\mathrm{m})$

$R \quad$ Ladle radius (m)

$R_{\text {av }} \quad$ Equivalent plume radius (m)

$L_{\text {model }} \quad$ Size of physical modeling ladle (m)

$L_{\text {prototype }} \quad$ Size of prototype ladle (m) 


\begin{tabular}{|c|c|}
\hline$\rho, \rho_{\mathrm{l}}, \rho_{\mathrm{g}}, \rho_{\mathrm{b}}$ & $\begin{array}{l}\text { Mixture density, liquid density, gas } \\
\text { density, and density of bubble } \\
\text { particles }\left(\mathrm{kg} \mathrm{m}^{-3}\right)\end{array}$ \\
\hline$\alpha_{1} \alpha_{\mathrm{g}}$ & $\begin{array}{l}\text { Liquid volume fraction and gas } \\
\text { volume fraction }\end{array}$ \\
\hline$\vec{u}, \vec{u}_{\mathrm{q}}, \vec{u}_{\mathrm{rel}}, u_{\mathrm{bi}}, U_{\mathrm{p}}$ & $\begin{array}{l}\text { Velocity component of mixture } \\
\text { fluid, velocity component of liquid } \\
\text { phase, relative velocity between gas } \\
\text { and liquid, bubble particle velocity, } \\
\text { and plume velocity }\left(\mathrm{m} \mathrm{s}^{-1}\right)\end{array}$ \\
\hline$Q$ & Gas flow rates $\left(\mathrm{m}^{3} \mathrm{~s}^{-1}\right)$ \\
\hline$g$ & Acceleration of gravity $\left(\mathrm{m} \mathrm{s}^{-2}\right)$ \\
\hline$p$ & Total pressure $\left(\mathrm{N} \mathrm{m}^{-2}\right)$ \\
\hline$\mu, \mu_{\mathrm{t}}$ & $\begin{array}{l}\text { Liquid viscosity and turbulent } \\
\text { viscosity }\left(\mathrm{kg} \mathrm{m}^{-1} \mathrm{~s}^{-1}\right)\end{array}$ \\
\hline$F_{\mathrm{s}}$ & Surface tension force $\left(\mathrm{N} \mathrm{m}^{-3}\right)$ \\
\hline & Surface tension coefficient $\left(\mathrm{N} \mathrm{m}^{-1}\right)$ \\
\hline & Curvature $\left(\mathrm{m}^{-2}\right)$ \\
\hline$B_{\mathrm{ag}, \mathrm{i}}, B_{\mathrm{br}, \mathrm{i}}$ & $\begin{array}{l}\text { Birth term due to aggregation and } \\
\text { birth term due to breakage }\end{array}$ \\
\hline$D_{\mathrm{ag}, \mathrm{i}}, D_{\mathrm{br}, \mathrm{i}}$ & $\begin{array}{l}\text { Death term due to aggregation and } \\
\text { death term due to breakage }\end{array}$ \\
\hline$F_{\mathrm{Di}}$ & Drag force $(\mathrm{N})$ \\
\hline$Q_{\mathrm{bi}}$ & $\begin{array}{l}\text { Bubble injection mass flow rate } \\
(\mathrm{kg} / \mathrm{s})\end{array}$ \\
\hline$\Delta t$ & Time-step (s) \\
\hline$\tau 95 \mathrm{pct}$ & Mixing time (s) \\
\hline$T_{1}, T_{\mathrm{g}}$ & $\begin{array}{l}\text { Liquid temperatures and gas } \\
\text { temperatures }(\mathrm{K})\end{array}$ \\
\hline & Eötvös number \\
\hline$F_{r}$ & Froude number \\
\hline
\end{tabular}

\section{REFERENCES}

1. D. Mazumdar and R.I.L. Guthrie: ISIJ Int., 1995, vol. 35, pp. 1-20.

2. L.F. Zhang and S. Taniguchi: Int. Mater. Rev., 2000, vol. 45, pp. 59-82.

3. K. Krishnapisharody and G.A. Irons: Metall. Mater. Trans. B, 2013, vol. 44B, pp. 1486-98.

4. S. Yu, Z.S. Zou, L. Shao, and S. Louhenkilpi: Steel Res. Int., 2017, vol. 88 , pp. $1-5$.

5. D. Sichen: Steel Res. Int., 2012, vol. 83, pp. 825-41.

6. G. Irons, A. Senguttuvan, and K. Krishnapisharody: ISIJ Int., 2015, vol. 55, pp. 1-6.

7. D. Mazumdar and J.W. Evans: ISIJ Int., 2004, vol. 44, pp. 44761.

8. S. Joo and R.I.L. Guthrie: Metall. Trans. B, 1992, vol. 23B, pp. 765-78.

9. Y. Sahai and R.I.L. Guthrie: Metall. Trans. B, 1982, vol. 13B, pp. 193-202.

10. K. Yonezawa and K. Schwerdtfeger: Metall. Mater. Trans. B, 1999, vol. 30B, pp. 411-18.

11. C.A. Llanos, S. Garcia-Hernandez, J.A. Ramos-Banderas, J.D. Barret, and G. Solorio-Diaz: ISIJ Int., 2010, vol. 50, pp. 396402.

12. K. Krishnapisharody, N.B. Ballal, P.K. Sinha, M.K. Sardar, and K.N. Jha: ISIJ Int., 1999, vol. 39, pp. 419-25.

13. R. González-Bernal, G. Solorio-Diaz, A. Ramos-Banderas, E. Torres-Alonso, C.A. Hernández-Bocanegra, and R. Zenit: Steel Res. Int., 2017, vol. 89, art. no. 1700281.

14. J. Mandal, S. Patil, M. Madan, and D. Mazumdar: Metall. Mater. Trans. B, 2005, vol. 36B, pp. 479-87.

15. N. Mazumdar, A. Mahadevan, M. Madan, and D. Mazumdar: ISIJ Int., 2005, vol. 45, pp. 1940-42.
16. S.P. Patil, D. Satish, M. Peranandhanathan, and D. Mazumdar: ISIJ Int., 2010, vol. 50, pp. 1117-24.

17. A.M. Amaro-Villeda, M.A. Ramirez-Argaez, and A.N. Conejo: ISIJ Int., 2014, vol. 54, pp. 1-8.

18. H.Y. Tang, X.C. Guo, G.H. Wu, and Y. Wang: ISIJ Int., 2016, vol. 56, pp. 2161-70.

19. Z.Q. Liu, L.M. Li, and B.K. Li: ISIJ Int., 2017, vol. 57, pp. 197179 .

20. A.S. Gómez, A.N. Conejo, and R. Zenit: J. Appl. Fluid Mech., 2018, vol. 11, pp. 11-20.

21. C.M. Fan and W.S. Hwang: Ironmak. Steelmak., 2002, vol. 29, pp. 415-26.

22. S. Asai, T. Okamoto, J.C. He, and I. Muchi: Trans. Jpn Inst. Met., 1983, vol. 23, pp. 43-50.

23. D. Mazumdar and R.I.L. Guthrie: Metall. Trans. B, 1986, vol. 17B, pp. 725-33.

24. D. Mazumdar, H.B. Kim, and R.I.L. Guthrie: Ironmak. Steelmak., 2000, vol. 27, pp. 302-09.

25. A.H. Castillejos and J.K. Brimacombe: Metall. Trans. B, 1987, vol. 18B, pp. 649-58.

26. A.H. Castillejos and J.K. Brimacombe: Metall. Trans. B, 1987, vol. 18 B, pp. $659-71$.

27. S.T. Johansen, D.G.C. Robertson, K. Woje, and T.A. Engh: Metall. Trans. B, 1988, vol. 19B, pp. 745-54.

28. S. Taniguchi, S. Kawaguchi, and A. Kikuchi: Appl. Math. Modell., 2002, vol. 26, pp. 249-62.

29. P.E. Anagbo and J.K. Brimacombe: Metall. Trans. B, 1990, vol. 21B, pp. 637-48.

30. Y.Y. Sheng and G.A. Irons: Int. J. Multiphase Flow, 1991, vol. 17, pp. 585-98.

31. Y.Y. Sheng and G.A. Irons: Metall. Mater. Trans. B, 1995, vol. 26B, pp. 625-35.

32. Y. Kishimoto, Y.Y. Sheng, G.A. Irons, and J.S. Chang: ISIJ Int., 1999, vol. 39, pp. 113-22.

33. M. Iguchi, H. Takeuchi, and Z. Morita: ISIJ Int., 1991, vol. 31, pp. 246-53.

34. M. Iguchi, H. Kawabata, K. Nakajima, and Z. Morita: Metall. Mater. Trans. B, 1995, vol. 26B, pp. 67-74.

35. Y.K. Xie and F. Oeters: Steel Res. Int., 1992, vol. 63, pp. 93-104.

36. Y.K. Xie, S. Orsten, and F. Oeters: ISIJ Int., 1992, vol. 32, pp. 66-75.

37. D. Guo and G.A. Irons: Metall. Mater. Trans. B, 2000, vol. 31B, pp. $1447-55$.

38. D. Guo and G.A. Irons: Metall. Mater. Trans. B, 2000, vol. 31B, pp. 1457-64.

39. L.M. Li, Z.Q. Liu, B.K. Li, H. Matsuura, and F. Tsukihashi: ISIJ Int., 2015, vol. 55, pp. 1337-46.

40. Y.G. Xu, M. Ersson, and P.G. Jonsson: Metall. Mater. Trans. B, 2015, vol. 46B, pp. 2628-38.

41. G.C. Wang, H.C. Zhou, Q.R. Tian, X.G. Ai, and L.F. Zhang: ISIJ Int., 2017, vol. 57, pp. 805-13.

42. T. Tatsuoka, C. Kamata, and K. Ito: ISIJ Int., 1997, vol. 37, pp. $557-61$

43. K. Sakaguchi and K. Ito: ISIJ Int., 1995, vol. 35, pp. 1348-53.

44. Y.J. Kang, L. Yu, and D. Sichen: Ironmak. Steelmak., 2007, vol. 34, pp. 253-61.

45. K. Malmberg, M. Nzotta, A. Karasev, and P.G. Jönsson: Ironmak. Steelmak., 2013, vol. 40, pp. 231-37.

46. M. Söder, P.G. Jönsson, and L. Jonsson: Steel Res. Int., 2004, vol. 75 , pp. $128-38$.

47. W.T. Lou and M.Y. Zhu: Metall. Mater. Trans. B, 2013, vol. 44B, pp. 762-82.

48. W.T. Lou and M.Y. Zhu: ISIJ Int., 2014, vol. 54, pp. 9-18.

49. A. Huang, H. Harmuth, M. Doletschek, S. Vollmann, and X.Z. Feng: Steel Res. Int., 2015, vol. 86, pp. 1447-54.

50. M. Thunman, S. Eckert, O. Hennig, J. Bjorkvall, and D. Sichen: Steel Res. Int., 2007, vol. 78, pp. 849-56.

51. P. Dayal, K. Beskow, J. Björkvall, and D. Sichen: Ironmak. Steelmak., 2006, vol. 33, pp. 454-64.

52. H.L. Yang, P. He, and Y.C. Zhai: ISIJ Int., 2014, vol. 54, pp. $578-81$.

53. C. Liu, S.F. Yang, J.S. Li, L.B. Zhu, and X.G. Li: Metall. Mater. Trans. B, 2016, vol. 47B, pp. 1882-92.

54. Y.L. Zhou, Z.Y. Deng, and M.Y. Zhu: Int. J. Miner. Metall. Mater., 2017, vol. 24, pp. 627-37. 
55. K. Krishnapisharody and G.A. Irons: Metall. Mater. Trans. B, 2006, vol. 37B, pp. 763-72.

56. D. Guo and G.A. Irons: Metall. Mater. Trans. B, 2002, vol. 33B, pp. $377-84$.

57. M. Iguchi, K. Miyamoto, S. Yamashita, D. Iguchi, and M. Zeze: ISIJ Int., 2004, vol. 44, pp. 636-38.

58. M. Peranandhanthan and D. Mazumdar: ISIJ Int., 2010, vol. 50, pp. $1622-31$.

59. L. Wu, P. Valentin, and D. Sichen: Steel Res. Int., 2010, vol. 81, pp. $508-15$.

60. N. Lv, L. Wu, H. Wang, Y. Dong, and C. Su: Int. J. Iron Steel Res., 2017, vol. 24, pp. 243-50.

61. D. Mazumdar, P. Dhandapani, and R. Sarvanakumar: ISIJ Int., 2017, vol. 57, pp. 286-95.

62. L.E.J. Pérez, A. Amaro-Villeda, A.N. Conejo, C. González-Rivera, and M.A. Ramirez-Argáez: Mater. Manuf. Process., 2018, vol. 33 , pp. $882-90$.

63. P. Valentin, C. Bruch, Y. Kyrylenko, H. Kochner, and C. Dannert: Steel Res. Int., 2009, vol. 80, pp. 552-58.

64. M. Ek, L. Wu, P. Valentin, and D. Sichen: Steel Res. Int., 2010, vol. 81, pp. 1056-63.

65. B. Glaser, M. Görnerup, and D. Sichen: Steel Res. Int., 2011, vol. 82, pp. 1425-34.

66. B. Glaser, M. Görnerup, and D. Sichen: Steel Res. Int., 2011, vol. 82 , pp. 827-35.

67. F. Karouni, B.P. Wynne, J. Talamantes-Silva, and S. Phillips: Steel Res. Int., 2018, vol. 89, art. no. 1700551.

68. K. Krishnapisharody and G.A. Irons: ISIJ Int., 2010, vol. 50, pp. 1413-21.

69. D. Mazumdar: Metall. Trans. B, 1990, vol. 21B, pp. 925-28.

70. Y.H. Pan, D.C. Guo, J.J. Ma, W.Z. Wang, F.P. Tang, and C. Li: ISIJ Int., 1994, vol. 34, pp. 794-801.

71. S.W.P. Cloete, J.J. Eksteen, and S.M. Bradshaw: Progr. Comput Fluid Dynam., 2009, vol. 9, pp. 345-56.

72. H.P. Liu, Z.Y. Qi, and M.G. Xu: Steel Res. Int., 2011, vol. 82, pp. $440-58$.

73. Y.L. Li, L.F. Zhang, and Y. Ren: Proc. Extraction and Processing Division Symp. on Pyrometallurgy in Honor of David G.C. Robertson, San Diego, CA, 2014, pp. 659-66.

74. D. Mazumdar and R.I.L. Guthrie: Metall. Mater. Trans. B, 1994, vol. 25 B, pp. 308-12.

75. M. Madan, D. Satish, and D. Mazumdar: ISIJ Int., 2005, vol. 45, pp. 677-85.

76. Q. Cao and L. Nastac: Metall. Mater. Trans. B, 2018, vol. 49B, pp. 1388-1404.

77. Y. Sahai and R.I.L. Guthrie: Metall. Trans. B, 1982, vol. 13B, pp. 125-27.

78. D. Mazumdar: Metall. Trans. B, 1989, vol. 20B, pp. 967-69.

79. Y. Sahai and R.I.L. Guthrie: Metall. Trans. B, 1982, vol. 13B, pp. 203-11.

80. D. Mazumdar and R.I.L. Guthrie: Metall. Trans. B, 1985, vol. 16B, pp. 83-90.

81. D. Mazumdar, R.I.L. Guthrie, and Y. Sahai: Appl. Math. Modell., 1993, vol. 17, pp. 255-62.

82. M.B. Goldschmit and A.H.C. Owen: Ironmak. Steelmak., 2001, vol. 28 , pp. 337-41.

83. S. Ganguly and S. Chakraborty: ISIJ Int., 2004, vol. 44, pp. 53746.

84. S. Ganguly and S. Chakraborty: Ironmak. Steelmak., 2008, vol. 35 , pp. $524-30$

85. Y.G. Xu, M. Ersson, and P. Jonsson: Steel Res. Int., 2015, vol. 86, pp. 1289-97.

86. B.K. Li, H.B. Yin, C.Q. Zhou, and F. Tsukihashi: ISIJ Int., 2008, vol. 48, pp. 1704-11

87. E.K. Ramasetti, V.-V. Visuri, P. Sulasalmi, and T. Fabritius: A CFD and Experimental Investigation of Slag Eye in Gas Stirred Ladle. Proc. 5th Int. Conf. on Fluid Flow, Canada, 2018.

88. G.N. Li: UDF to Count the Number of Droplets in a VOF Simulation. http://www.eureka.im/1249.html, 2007.

89. P. Sulasalmi, V.-V. Visuri, A. Kärnä, and T. Fabritius: Steel Res. Int., 2015, vol. 86, pp. 212-22.

90. P. Sulasalmi, A. Kärnä, T. Fabritius, and J. Savolainen: ISIJ Int., 2009, vol. 49, pp. 1661-67.
91. A. Senguttuvan: Doctoral Thesis, McMaster University, Hamilton, ON, Canada, 2016.

92. A. Senguttuvan and G.A. Irons: ISIJ Int., 2017, vol. 57, pp. $1962-70$.

93. Y.G. Xu, M. Ersson, and P.G. Jönsson: ISIJ Int., 2016, vol. 56, pp. $1982-88$.

94. M. Ersson, L. Höglund, A. Tilliander, L. Jonsson, and P.G. Jönsson: ISIJ Int., 2008, vol. 48, pp. 147-53.

95. U. Singh, R. Anapagaddi, S. Mangal, K.A. Padmanabhan, and A.K. Singh: Metall. Mater. Trans. B, 2016, vol. 47B, pp. 1804-16.

96. W.T. Lou and M.Y. Zhu: Metall. Mater. Trans. B, 2013, vol. 44B, pp. 1251-63.

97. O.J. Ilegbusi, M. Iguchi, K. Nakajima, M. Sano, and M. Sakamoto: Metall. Mater. Trans. B, 1998, vol. 29B, pp. 211-22.

98. L.F. Zhang: Modelling Simul. Mater. Sci. Eng., 2000, vol. 8, pp. 463-76.

99. V. De Felice, I.L.A. Daoud, B. Dussoubs, A. Jardy, and J.P. Bellot: ISIJ Int., 2012, vol. 52, pp. 1273-80.

100. J.P. Bellot, V. De Felice, B. Dussoubs, A. Jardy, and S. Hans: Metall. Mater. Trans. B, 2014, vol. 45B, pp. 13-21.

101. D.Y. Sheng, M. Söder, P. Jönsson, and L. Jonsson: Scand. J. Metall., 2002, vol. 31, pp. 134- 47.

102. M. Söder, P. Jönsson, and J. Alexis: Scand. J. Metall., 2002, vol. 31, pp. 210-20.

103. M. Söder: Doctoral Thesis, KTH Royal Institute of Technology, Stockholm, 2004, 91-7283-886-8.

104. D.B. Spalding: Math. Comput. Simul., 1981, vol. 23, pp. 26776.

105. D.B. Spalding: Numerical Computation of Multi-Phase Fluid Flow and Heat Transfer, Pineridge Press, London, 1980, pp. 139-67.

106. L. Jonsson and P. Jönsson: ISIJ Int., 1996, vol. 36, pp. 1127-34.

107. P.G. Jönsson, L. Jonsson, and D. Sichen: ISIJ Int., 1997, vol. 37, pp. 484-91.

108. L. Jonsson, D. Sichen, and P. Jönsson: ISIJ Int., 1998, vol. 38, pp. $260-67$.

109. J.L. Xia, T. Ahokainen, and L. Holappa: Scand. J. Metall., 2001, vol. 30 , pp. $69-76$.

110. C.G. Mendez, N. Nigro, and A. Cardona: J. Mater. Process. Technol., 2005, vol. 160, pp. 296-305.

111. L.T. Wang, Q.Y. Zhang, S.H. Peng, and Z.B. Li: ISIJ Int., 2005, vol. 45 , pp. $331-37$.

112. L.T. Wang, S.H. Peng, Q.Y. Zhang, and Z.B. Li: Steel Res. Int., 2006, vol. 77, pp. 25-31.

113. D.Q. Geng, H. Lei, and J.C. He: Int. J. Miner. Metall. Mater., 2010, vol. 17, pp. 709-14.

114. F.D. Maldonado-Parra, M.A. Ramirez-Argáez, A.N. Conejo, and C. González: ISIJ Int., 2011, vol. 51, pp. 1110-18.

115. A. Huang, H.Z. Gu, M.J. Zhang, N. Wang, T. Wang, and Y. Zou: Metall. Mater. Trans. B, 2013, vol. 44B, pp. 744-49.

116. W.T. Lou and M.Y. Zhu: Metall. Mater. Trans. B, 2014, vol. $45 \mathrm{~B}$, pp. $1706-22$.

117. W.T. Lou and M.Y. Zhu: ISIJ Int., 2015, vol. 55, pp. 961-69.

118. S. Yu and S. Louhenkilpi: Metall. Mater. Trans. B, 2013, vol. 44B, pp. 459-68.

119. S. Yu, J. Miettinen, and S. Louhenkilpi: Mater. Sci. Forum, 2013, vol. 762 , pp. $253-59$.

120. S. Yu, J. Miettinen, and S. Louhenkilpi: Steel Res. Int., 2014, vol. 85, pp. 1393-1402.

121. S. Yu, J. Miettinen, L. Shao, and S. Louhenkilpi: Steel Res. Int., 2015, vol. 86, pp. 466-77.

122. S. Yu: Doctoral Thesis, Aalto University, Helsinki, 2014.

123. J. Aoki, L. Zhang, and B.G. Thomas: 3rd Int. Congr. on Science \& Technology of Steelmaking, Warrendale, PA, 2005, pp. 31932.

124. R. Singh, D. Mazumdar, and A.K. Ray: ISIJ Int., 2008, vol. 48, pp. 1033-35.

125. L.M. Li, B.K. Li, and Z.Q. Liu: ISIJ Int., 2017, vol. 57, pp. 1-10.

126. L.M. Li, Z.Q. Liu, M.X. Cao, and B.K. Li: JOM, 2015, vol. 67, pp. 1459-67.

127. T. Kulju, S. Ollila, R.L. Keiski, and E. Muurinen: IFAC-PapersOnLine, 2015, vol. 48, pp. 1-5.

128. T. Stapurewicz and N.J. Themelis: Can. Metall. Q., 1987, vol. 26, pp. 123-28. 
129. A.K. Singh and D. Mazumdar: Metall. Mater. Trans. B, 1997, vol. 28B, pp. 95-102.

130. J. Savolainen, T. Fabritius, and O. Mattila: ISIJ Int., 2009, vol. 49 , pp. 29-36.

131. C.E. Grip, L. Jonsson, P.G. Jönsson, and K.O. Jonsson: ISIJ Int., 1999, vol. 39, pp. 715-21.
132. J.T. Kuo and G.B. Wallis: Int. J. Multiphase Flow, 1988, vol. 14, pp. 547-64.

133. S.W. Beyerlein, R.K. Cossmann, and H.J. Richter: Int. J. Multiphase Flow, 1985, vol. 11, pp. 629-41.

134. S.A. Morsi and A.J. Alexander: J. Fluid Mech., 1972, vol. 55, pp. 193-208. 